\title{
Review Article \\ On the Role of Climate Forcing by Volcanic Sulphate and Volcanic Ash
}

\author{
Baerbel Langmann \\ Institute of Geophysics, University of Hamburg, Geomatikum, Office 1411, Bundesstraße 55, 20146 Hamburg, Germany \\ Correspondence should be addressed to Baerbel Langmann; baerbel.langmann@zmaw.de
}

Received 27 October 2013; Accepted 7 January 2014; Published 27 February 2014

Academic Editor: Klaus Dethloff

Copyright (C) 2014 Baerbel Langmann. This is an open access article distributed under the Creative Commons Attribution License, which permits unrestricted use, distribution, and reproduction in any medium, provided the original work is properly cited.

There is overall agreement that volcanic sulphate aerosols in the stratosphere can reduce solar radiation reaching the earth's surface for years, thereby reducing surface temperatures, affecting global circulation patterns and generally the global climate system. However, the response of the climate system after large volcanic eruptions is not fully understood and global climate models have difficulties to reproduce the observed variability of the earth system after large volcanic eruptions until now. For geological timescales, it has been suggested that, in addition to the stratospheric climate forcing by volcanic sulphate aerosols, volcanic ash affects climate by modifying the global carbon cycle through iron fertilising the surface ocean and stimulating phytoplankton growth. This process has recently also been observed after the eruption of the volcano Kasatochi on the Aleutian Islands in summer 2008. To trigger future research on the effect of volcanic ash on the climate system via ocean iron fertilisation, this review paper describes the formation processes and atmospheric life cycles of volcanic sulphate and volcanic ash, contrasts their impact on climate, and emphasises current limitations in our understanding.

\section{Introduction}

Volcanic emissions are an important source of atmospheric gases, aerosols, and ash [1-3]. Volcanic ash is formed by fragmentation processes of the magma and the surrounding rock material within volcanic vents $[1,4]$. Volcanic gas emissions from the magma consist primarily of $\mathrm{H}_{2} \mathrm{O}$, followed by $\mathrm{CO}_{2}$, $\mathrm{SO}_{2}, \mathrm{H}_{2} \mathrm{~S}, \mathrm{HCl}, \mathrm{HF}$, and other compounds [5]. Secondary products like volcanic sulphate aerosols result from high- and low-temperature chemical transformation processes in the conduit, the volcanic plume, and cloud [6-9].

When volcanic emissions are released into the free troposphere or stratosphere $[1,6]$, they are transported by the prevailing winds and modified photochemically and microphysically before being removed from the atmosphere by gravitational settling and wet deposition. Posteruptive remobilisation of volcanic ash from its deposits represents another source for volcanic ash in the atmosphere [10-15].

Since the volcanic eruptions of El Chichón in 1982 and Mt. Pinatubo in 1991, the importance of volcanic ash for climate has been considered negligible, whereas the climate forcing of volcanic sulphate received increasing attention [16].
Today, it is widely accepted in the climate and volcanological research communities that the major climate forcing effect following explosive volcanic eruptions is through their emission of sulphur species into the stratosphere. These are mainly in the form of $\mathrm{SO}_{2}$ [17-19] and sometimes also $\mathrm{H}_{2} \mathrm{~S}$ [20-23]. They are oxidised to sulphate aerosols within weeks. Volcanic sulphate aerosols in the stratosphere can reduce solar radiation reaching the earth's surface for years, thereby reducing surface temperatures and affecting global circulation patterns and generally the global climate system [6]. Several previous reviews discuss the effects of volcanoes on climate, for example, references [24-32]. Except [24], all of these studies focus on the climatic effect of volcanic sulphate aerosols. According to [6,31], volcanic ash and tephra (tephra definition: fragmental matter of any size and composition created during a volcanic eruption; [2]) have very small climatic impacts, which are restricted to the residence time of these particles in the atmosphere. In contrast to volcanic gases and aerosols, volcanic ash is removed from the atmosphere more rapidly after an eruption. Only submicron volcanic ash particles have been observed for several months in the lower stratosphere following major volcanic eruptions $[33,34]$. 
During a period of up to few weeks the huge atmospheric load of volcanic ash close to the source region may affect the amplitude of the diurnal cycle of surface air temperature.

However, $[6,30,31]$ neglect the impact that volcanic ash has on the biogeochemistry of the ocean; volcanic ash may activate the "biological pump," a process that converts $\mathrm{CO}_{2}$ to organic carbon and allows organic matter particles to sink to the deep ocean, thereby reducing atmospheric $\mathrm{CO}_{2}$. Recent work showed that airborne material from volcanic eruptions, in particular volcanic ash, modifies the biogeochemical processes in the surface ocean [35-39], thereby directly affecting climate. References [40,41] first speculated about oceanic iron-induced biogeochemical processes by volcanic ash after the 1991 Pinatubo eruption. However, these processes remained largely unconsidered in the volcano-climate research community until the eruption of Kasatochi volcano on the Aleutian Islands in August 2008. After this eruption, favourable atmospheric and oceanic conditions in the NE Pacific enabled the formation of an immense phytoplankton bloom, observed over a wide area by satellite instruments [36], in situ measurements [42, 43], and modelling studies [44]. This event was the first to confirm that volcanic ash can successfully fertilise the surface ocean, potentially having an effect on climate. Volcanic ash can therefore play a role similar to mineral dust, which is commonly assumed to dominate external iron supply to the open ocean [45].

In this review climatic effects of volcanic ash versus those of volcanic sulphate are discussed and new light is shed on the effects of volcanic eruptions on climate (Figure 1). The review aims to stimulate new discussions and joint and interdisciplinary research projects involving research communities specialised in ocean biogeochemistry and biology, volcanology, geochemistry, meteorology, atmospheric chemistry, and climate. An improved understanding of natural causes of climate change-including volcanic eruptions-is indispensable when interpreting natural climate variability, even in the era of anthropogenic climate change. The following Sections 2 and 3 describe the fate of volcanic ash and sulphate chronologically from the formation processes over the atmospheric burden to postatmospheric deposition. Climate forcing is presented in Section 4. Section 5 provides an outlook on future research needs.

\section{Formation Processes and Chemical and Physical Characteristics}

2.1. Frequency of Volcanic Eruptions. Annually, 50-70 volcanic eruptions lasting from hours to years occur worldwide with about 20 volcanoes erupting at any defined date [46]. Volcanic eruptions with a Volcanic Explosivity Index (VEI, relative measure of the explosiveness of volcanic eruption; [18]) smaller than 4 are most numerous. Volcanic ash emission into the troposphere from these small eruptions is estimated to $20 \mathrm{Tg} / \mathrm{yr}$ [47]. However, before the satellite era, our knowledge of volcanic eruptions with VEI $\leq 4$ is limited because of restricted observation capabilities of remote volcanic eruptions. Nevertheless, these ash emissions are only of local interest due to rapid deposition out of the atmosphere. Reference [48] summarises ash emissions from major volcanic eruptions since 1900 with VEI $\geq 4$ and with a tephra release ranging from 0.1 to $100 \mathrm{~km}^{3}$. During such volcanic eruptions, volcanic ash can undergo longrange transport and submicron ash particles may survive for months in the atmosphere $[33,34]$.

Sulphur containing gases contribute typically $2-35 \%$ to the volcanic gas emissions [31] with values of 14-21 Tg/yr for $\mathrm{SO}_{2}[21,49]$ and 1-37 Tg/yr for $\mathrm{H}_{2} \mathrm{~S}$ [21]. Although global sulphur emissions from volcanoes make up only $\sim 14 \%$ of the total natural and anthropogenic sulphur emissions [49], they have a much larger relative contribution to radiative and climate effects (see Section 4). As volcanic emissions are mainly released above the atmospheric boundary layer due to the height of volcano summits, they have longer lifetimes than anthropogenically released sulphur compounds (see Section 3).

\subsection{Chemical and Mechanical Processes below the Earth Sur-} face. The erupting magma mainly determines the chemical composition of volcanic ash with a silica content between about 45 and 75 wt-\% [50] and melting temperatures between $\sim 650$ and $\sim 1200^{\circ} \mathrm{C}$. Reference [51] analysed volcanic ash from the 1989 Redoubt eruption (Alaska) and found that the ash consisted of $70 \mathrm{wt}-\%$ of silica glass and $30 \mathrm{wt}-\%$ of minerals. Volcanic ash minerals like feldspar, olivine, pyroxene, hornblende, biotite, magnetite, and ilmenite [52] have their origin in a sequential crystallisation process, which is driven by cooling and decompression during the rise of the magma through the earth's crust.

When magma containing dissolved volatiles like $\mathrm{H}_{2} \mathrm{O}$, $\mathrm{CO}_{2}, \mathrm{SO}_{2}, \mathrm{H}_{2} \mathrm{~S}, \mathrm{HCl}, \mathrm{HF}$, and other compounds [5] rises through the earth's mantle and crust into the conduit, volatiles get separated from the magma in form of gas bubbles eventually triggering an explosive eruption [1]. During explosive volcanic eruptions with rhyolitic magma, usually abundant fragmentation of magma is observed. However, plinian (highly explosive) volcanic eruptions occur also at volcanoes with andesitic magma composition, for example, at Shiveluch, Kamchatka [53].

There is ongoing discussion about the differing amount of volcanic $\mathrm{SO}_{2}$ emissions from explosive volcanic eruptions as measured by petrological methods and remote sensing [54-56]. The expression of "excess sulphur" was introduced to describe the much lower dissolved sulphur concentration in magmas (by 1 to 2 orders of magnitude) in comparison to the total mass of $\mathrm{SO}_{2}$ released during an eruption as measured by remote sensing techniques [56]. Petrological data provide a minimum estimate of the erupted sulphur [57] because the melt droplets included in the magma, which are analysed to estimate the pre-eruptive sulphur content, do not account for any eruptive phase chemical conversion. Excess eruptive sulphur is observed particularly during explosive eruptions of intermediate and silicic magma in subduction zone settings $[58,59]$ rather than for basaltic eruptions from divergent plate boundaries and hot spots. Reference [60] proposed that arc magmas coexist with a substantial vapour phase in crustal storage regions. According to [61, 62], shallow 


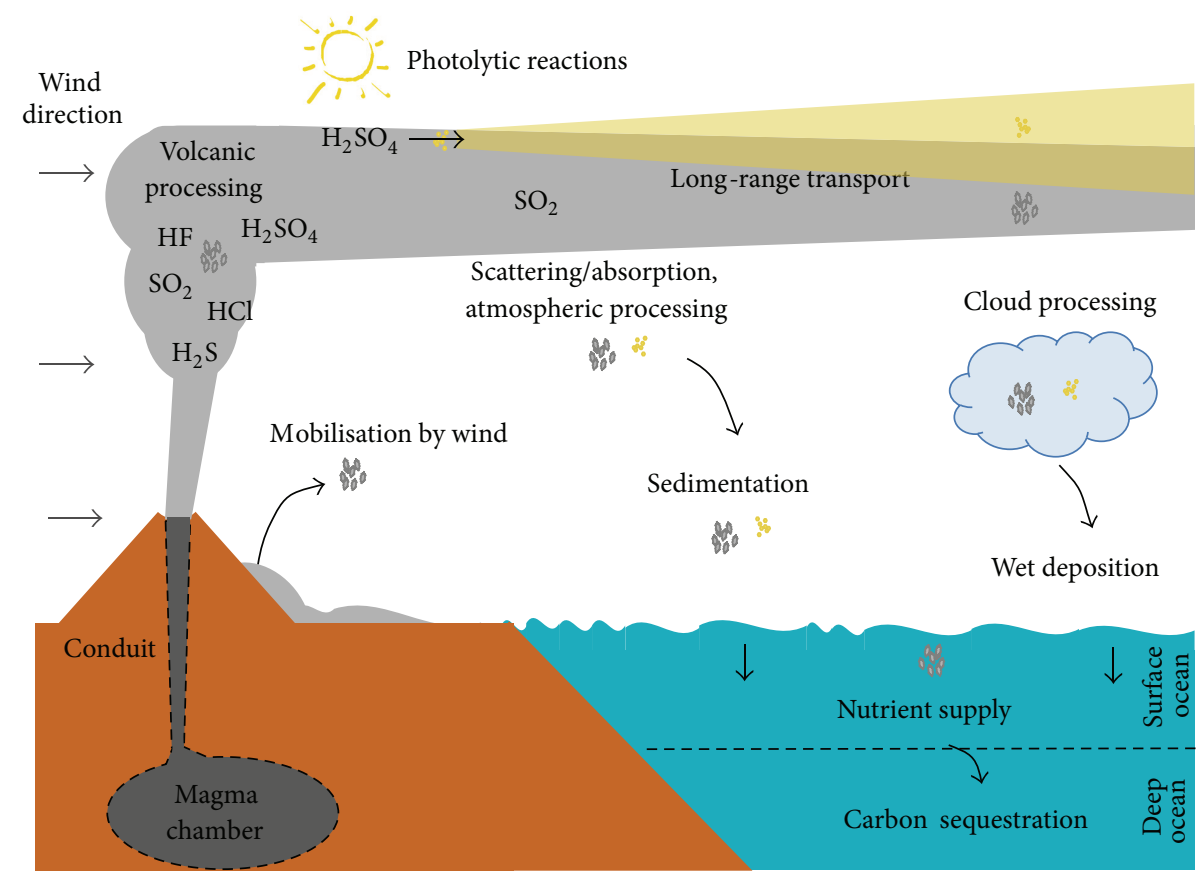

FIGURE 1: Schematic diagram showing the important processes controlling climate effects of volcanic ash (in grey) and volcanic sulphate (in yellow).

silicic magma chambers may be recharged with volatiles supplied by mafic magmas that have been differentiated in a lower crustal "hot zone". At high pressure, supercritical fluids, which are formed by fractional crystallisation of vapoursaturated melts, trigger the exsolution of a few wt- $\% \mathrm{H}_{2} \mathrm{O}$, $\mathrm{CO}_{2}$, and other volatiles and coexist with mafic melts or segregates from these compounds, that move independently through the crust [63]. Reference [64] presents evidence for deep degassing beneath Popocatepetl, Mexico, by showing melt inclusions with high concentrations of $\mathrm{CO}_{2}$ and $\mathrm{S}$ (above 1000 and 2000 ppm, resp.) indicating that degassing begins at depths of at least $25 \mathrm{~km}$. Two other mechanisms are proposed by [59] to explain the excess sulphur phenomenon: (a) eruption of bubble enriched magma and (b) degassing of a convective magma column. Another process leading to $\mathrm{SO}_{2}$ formation taking place in the hot core of volcanic plumes is presented in [65] and is discussed in Section 2.3.

Reference [7] reports about the high-temperature scavenging of volcanic $\mathrm{SO}_{2}$ by volcanic ash with potential important modifications of volcanic ash surfaces under cooler conditions. The authors suggest that extensive in-conduit $\mathrm{SO}_{2}$ scavenging by tephra from 7 to $45 \%$ may take place during large eruptions where fragmentation of magma already occurs close to the magma chamber $[66,67]$. Surprisingly, the interaction of $\mathrm{SO}_{2}$ with tephra at high temperature in volcanic conduits and eruption plumes has long not been considered in discussions related to $\mathrm{SO}_{2}$ scavenging [6870]. Reference [7], however, points to a consumption process of volatile sulphur, which would increase the discrepancies between petrological and remote sensing measurements even more.
2.3. Chemical and Mechanical Processing in Volcanic Plumes. The volcanic eruption plume is defined as the volume above the vent up to the level of neutral buoyancy (Figure 1) characterised by the major updraft motion. Turbulent motion dilutes the gas-particle mixture released from the vent by entraining ambient atmospheric water vapour into the plume thereby generating buoyancy. In addition, changes of the aggregation state of water redistribute energy in the volcanic eruption plume. In this volume volcanic ash and gases are cooled form about $1000^{\circ} \mathrm{C}$ to less than $0^{\circ} \mathrm{C}$ in only a few minutes [1, 31] and major fragmentation processes of volcanic ashes occur. The size distribution of volcanic ash is considerably dependent on the eruption conditions. During the eruption of a single volcano, the eruption conditions may change on timescales of seconds, so that fragmentation processes due to explosive eruptions (see Section 2.2), phreatomagmatic eruptions, pyroclastic flows, and coignimbrite clouds are superimposed. During phreatomagmatic eruptions [1], external cold water from, for example, glaciers (early phase of the Eyjafjallajökull eruption [71]), crater lakes, or the shallow ocean [72] chills the erupting hot magma. The subsequent shattering process leads to a powerful explosive eruption and an efficient production of fine-grained volcanic ash. Pyroclastic flows are resulting from collapsing eruption columns with low buoyancy producing impetuous tephra flows along the slopes of a volcano [1]. When the conditions at the top of a pyroclastic flow evolve to exceed the buoyancy of the ambient air, coignimbrite clouds can develop.

During basaltic eruptions, volcanic ash particles with diameters less than $30 \mu \mathrm{m}\left(\mathrm{PM}_{30}\right.$, particulate matter with diameters smaller than $30 \mu \mathrm{m}$ ) represent a minor fraction 
in contrast to rhyolitic eruptions, where a contribution of $30-50 \%$ to the total ash content is observed [3]. However, the knowledge about $\mathrm{PM}_{10}$ and $\mathrm{PM}_{2.5}$ ash particles, which undergo long-range transport, is relatively sparse in the volcanology research community, although such small-scale ash particles have been observed in the atmosphere for several months after volcanic eruptions $[33,34]$. Volcanic ash particle density varies between 2 and $3 \mathrm{~g} / \mathrm{cm}^{3}[2,73]$ and is a function of magma composition and fraction of crystallisation and porosity [74]. In addition, in the volcanic eruption plume, quenching processes may produce part of the glass material contained in volcanic ash. Beside the rapid cooling during updraft and entrainment of ambient air, lightning strokes in the volcanic eruption plume $[75,76]$ may contribute to quenching as well as to dry volcanic ash aggregation of charged ash particles (see Section 3) and to modifications of the volcanic ash and gas chemical composition, for example, incomplete crystallisation reactions (see Section 2.2).

According to [65], $\mathrm{SO}_{2}$ injection into the atmosphere is not essentially generated directly from shallow or deep magma systems but it can be produced in the hot core $(\mathrm{T}>$ $600^{\circ} \mathrm{C}$ ) of a volcanic plume as the result of $\mathrm{H}_{2} \mathrm{~S}$ oxidation. The hot core of volcanic plumes is considered the main cause of changes in the sulphur speciation [77, 78]. Also, [79] showed that the redox state of magma recorded at depth does not necessarily mirror that of its escaping gases. Depending on the initial oxidation state, the hot core of a volcanic plume can function as a reactor for $\mathrm{SO}_{2}$ formation and convert an initially $\mathrm{SO}_{2}$-poor mixture (reflecting the petrologic estimate) to a $\mathrm{SO}_{2}$-rich mixture (reflecting the remote sensing observation). Therefore, these studies represent another explanation for the differences in atmospheric measurements of $\mathrm{SO}_{2}$ after volcanic eruptions and the source conditions (see Section 2.2).

Further chemical conversions of sulphur containing gases and particles take place in the mid- and low-temperature regions of volcanic plumes [8]. Reference [80] proposed a sulphuric acid dew point in the eruption plume of $338^{\circ} \mathrm{C}$. However, this dew point temperature is only valid for very high concentrations of sulphuric acid at ambient pressure [81] and therefore only partly is a reasonable estimate for volcanic plumes. Reference [8] showed that $T \sim 150^{\circ} \mathrm{C}$ and $\sim 50^{\circ} \mathrm{C}$ are more reliable estimates for the dew point temperatures in volcanic plumes of sulphuric acid and water, respectively. After sulphuric acid condensation starts at $T \sim$ $150^{\circ} \mathrm{C}$, the concentration of sulphuric acid droplets increases and reaches a plateau close to $50^{\circ} \mathrm{C}$. At this temperature, water vapour condensation starts followed by the dissolution of the surrounding gases in the liquid water film [69]. Due to dissociation in liquid water, gaseous $\mathrm{H}_{2} \mathrm{SO}_{4}$ is rapidly depleted. Further physicochemical processes at temperatures less than $50^{\circ} \mathrm{C}$, where due to the presence of a liquid water film around volcanic ash particles, aqueous chemistry reactions become increasingly important, are discussed in Section 2.4.

Also at temperature above $50^{\circ} \mathrm{C}$ (in the absence of liquid water), the gases and secondary compounds produced from the initial volcanic gases may react with volcanic ash within the eruption plume, thereby producing soluble compounds on the volcanic ash surfaces $[68,80,82]$. It is assumed that
$30-40 \%$ of the sulphur species and $10-20 \%$ of the chlorine species, which are released during a volcanic eruption, are scavenged by volcanic ash $[68,83]$. The presence of soluble compounds on volcanic ash surfaces has been shown by a number of leaching experiments with pristine volcanic ash in water [84]. Beside various sulphate and halide compounds, biologically relevant elements such as $\mathrm{N}, \mathrm{P}, \mathrm{Si}, \mathrm{Fe}, \mathrm{Cd}$, $\mathrm{Co}, \mathrm{Cu}, \mathrm{Mn}, \mathrm{Mo}, \mathrm{Pb}$, and $\mathrm{Zn}$ have been measured [35, 85, 86]. Different explanations for this leaching behaviour have been proposed in the literature [48], for example, adsorption of volcanic salts on volcanic ash surfaces $[87,88]$, condensation of sulphuric acid on volcanic ash surfaces [68], acid dissolution of ash surface material, and deposition of secondary minerals and salts on volcanic ash surfaces [89]. Altogether, the processes at the ash particle surfaces are incompletely understood until today [90], so improvements in the scientific understanding are urgently required.

2.4. Chemical Processing in Volcanic Clouds. Once the volcanic plume has reached neutral buoyancy conditions, the volcanic cloud spreads out quasi horizontally (Figure 1) and further chemical and microphysical modifications of sulphur containing compounds and volcanic ash surfaces take place at ambient temperatures. When volcanic ash and volcanic gases are released at different injection heights (e.g., 1991 eruption of Pinatubo; [91]), such interactions are limited. However, chemical reactions like acid processing on volcanic ash surfaces may occur when the major injection altitudes of volcanic ash and gas are similar (e.g., during the eruption of Kasatochi in 2008; [92]). Fast sedimentation of large volcanic ash particles also restricts the possibilities of volcanic ash and volcanic gases to interact. However, sedimentation of submicron volcanic ash particles is relatively slow, so they have been observed for months in the lower stratosphere, for example, after the 1991 Pinatubo eruption [33, 34], allowing the condensation of volcanic gases followed by acid processing of volcanic ash surfaces.

In the presence of volcanic ash, water vapour condensation on the volcanic ash surface starts at about $50^{\circ} \mathrm{C}$. Gaseous sulphuric acid rapidly dissolves in this film of water and dissociates to $\mathrm{H}^{+}$and $\mathrm{HSO}_{4}{ }^{-}$, so more than $80 \%$ of the mass of the sulphuric acid is transferred out of the gas phase [8]. The scavenging of $\mathrm{SO}_{2}$ by water depends on the availability of other acidic gases. In general, the solubility of acid gases decreases with increasing acidity of the aqueous phase. $\mathrm{HCl}$ has four orders of magnitude higher solubility than $\mathrm{SO}_{2}$ and therefore hinders the scavenging of $\mathrm{SO}_{2}$ [93]. Model simulations in the absence of $\mathrm{HCl}$ remove $15 \%$ of the $\mathrm{SO}_{2}$ from the gas phase, whereas in the presence of $\mathrm{HCl}$ less than $5 \%$ of the $\mathrm{SO}_{2}$ is scavenged by the liquid water and more than $99 \%$ of the $\mathrm{HCl}$ is removed out of the gas phase [8]. In contrast, $\mathrm{H}_{2} \mathrm{~S}$ is only slightly soluble in liquid water, so its removal by cloud and raindrops at lower altitudes is negligible [31].

In the troposphere, cloud processing drives the efficient uptake of acid gases by aerosols [94], including volcanic ash particles [95]. As the lifetime of clouds is limited, they 


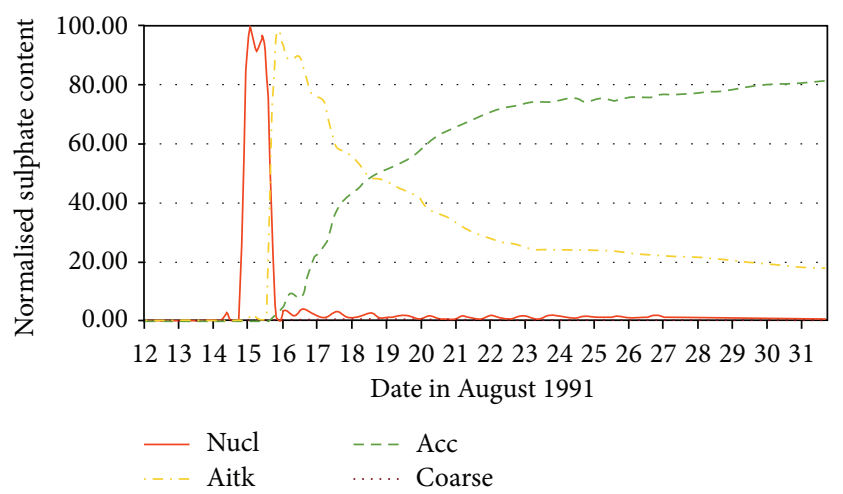

(a)

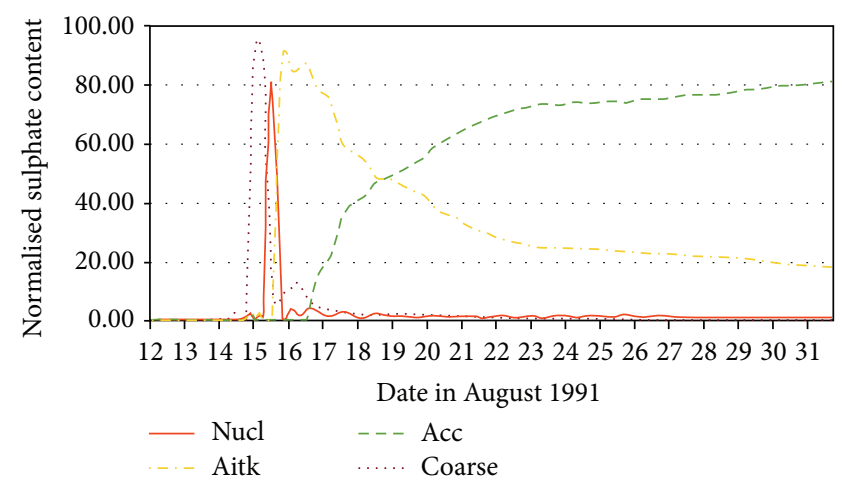

(b)

Figure 2: Modelled size distribution of sulphate aerosols during and after the 1991 volcanic eruption of Mt. Hudson (a) without and (b) with volcanic ash, normalised to the total amount of sulphate (100\%). Red line: nucleation mode; yellow line: Aitken mode; green line: accumulation mode; brown line: coarse mode.

can form and evaporate several times [94] during the longrange transport of volcanic ash particles in the atmosphere. After evaporation of cloud water, the thin film of aqueous electrolyte around each particle may reach $\mathrm{pH}$ values smaller than $2[96,97]$. Such low $\mathrm{pH}$ values contribute considerably to, for example, iron solubility in aerosols like mineral dust [98-100], but until today, the scientific understanding of these processes remains limited. Only a few studies investigated atmospheric processing of volcanic ash and gases at freezing temperatures, indicating considerable scavenging of volcanic gases like $\mathrm{SO}_{2}, \mathrm{H}_{2} \mathrm{~S}$, and $\mathrm{HCl}$ by ice particles and increased iron solubility $[69,101]$.

During ash-free volcanic eruptions or when volcanic gases and their secondary products are separated from volcanic ash and $\mathrm{SO}_{2}$ and $\mathrm{H}_{2} \mathrm{~S}$ are injected into the stratosphere, they are mainly oxidised by reactions with $\mathrm{OH}$ to sulphuric acid on a timescale of days to weeks $[6,94$, 102]. Sulphuric acid vapour is further converted to sulphate aerosols through the formation of new particles via binary homogenous nucleation involving sulphuric acid vapour and water vapour. This was observed after the 1991 eruption of Mt. Pinatubo, with an increase of 1-2 orders of magnitude in the concentration of condensation nuclei [103] and by $98 \%$ of the observed stratospheric aerosol being volatile [104, 105]. The condensation of sulphuric acid vapour onto existing particles shifts the particle size distribution to greater radii [106]. Coagulation of aerosols represents another particle growth process, which is a function of particle size and particle number concentration [107]. Observations after the 1991 Pinatubo eruption indicate that it takes about three months to reach a peak in stratospheric sulphate aerosol concentrations $[34,103]$. The sulphate aerosol particle density is assumed to lie in the range from 1.6 to $2.0 \mathrm{~g} / \mathrm{cm}^{3}[49,108-$ 110].

An exemplary model simulation study during the $1991 \mathrm{Mt}$. Hudson volcanic eruption in Chile illuminates the sulphate aerosol development [111]. In the absence of volcanic ash (Figure 2(a)), the sulphate aerosol formation process starts through nucleation $(d<0.01 \mu \mathrm{m})$ on August 14. By August
16, condensation and coagulation drive the formation of Aitken mode sulphate particles ( $d$ : $0.01-0.1 \mu \mathrm{m}$, named after John Aitken), which further grow into the accumulation size mode $(d: 0.1-1.0 \mu \mathrm{m})$, which forms the dominating mode from August 19 onwards. In the presence of volcanic ash (Figure 2(b)), coarse mode sulphate aerosols $(d>1 \mu \mathrm{m})$, which are formed by condensation of sulphuric acid vapour on coarse mode volcanic ash, dominate during the first hours of the eruption. Due to rapid sedimentation of volcanic ash, these coarse particles are soon separated from the gaseous sulphur containing atmospheric layers, so sulphate aerosol formation occurs mainly through nucleation later the day. The further development in sulphate aerosol size distribution is comparable to the non-volcanic ash situation. When submicron volcanic ash particles are injected into the stratosphere, they may survive in the lower stratosphere for months due to their slow sedimentation [33,34]. In the presence of $\mathrm{SO}_{2}$ and its oxidation products, volcanic ash is coated with aqueous $\mathrm{H}_{2} \mathrm{SO}_{4}$ with potential subsequent effects on the solubility of minerals at the volcanic ash surface (see Section 4.4).

\section{Atmospheric Burden, Residence Time, and Deposition}

Volcanic ash and sulphate atmospheric concentrations are highly variable in space and time dependent on the volcanic activity, the location of a volcanic eruption, and the atmospheric dispersion patterns upwind from the volcano. Volcanic ash mass concentrations measured in the troposphere during the eruption of Eyjafjallajökull, Iceland, in 2010, range from daily mean near surface concentrations of $400 \mu \mathrm{g} / \mathrm{m}^{3}$ in Scandinavia [112] to maximum ash concentrations of about $4000 \mu \mathrm{g} / \mathrm{m}^{3}$ in the volcanic ash cloud transported over Europe [112, 113]. On Iceland, daily average near surface concentration exceeded $1000 \mu \mathrm{g} / \mathrm{m}^{3}$ during the ongoing eruption of Eyjafjallajökul and also afterwards during resuspension events [15]. For a more detailed summary 
on volcanic ash resuspension events after various volcanic eruptions (Eyjafjallajökull 2010; Hudson 1991; Katmai, 1912) see [48].

In the lower stratosphere, [114] discovered a sulphate aerosol layer under undisturbed conditions with a global sulphate load in the order of $0.15 \mathrm{Tg}$ Sulphur [115]. Volcanic sulphate aerosols significantly enhance this stratospheric background sulphate concentration over a couple of years [6]. The e-folding decay time of stratospheric sulphate is approximately one year [116-119]. Once injected or formed in the stratosphere, $\mathrm{SO}_{2}$ and sulphate particles are rapidly advected around the globe. After the 1883 Krakatau eruption, sulphate aerosols circled the globe within two weeks [120]. The volcanic sulphate aerosols from the 1982 El Chichón [121] and 1991 Pinatubo cloud [122] required three weeks to circle the globe. Volcanic gases and particles produced from high-latitude volcanic eruptions may encircle the poles faster due to the shorter pathway and higher wind speed. Mt. Hudson, Chile (1991) emissions were transported around Antarctica in 10 days $[123,124]$. About two weeks were necessary for volcanic emissions from Kasatochi, Alaska (2008) (http://www.doas-bremen.de/images/highlights/ gome2_so2_kasatochi_large.gif), and Puyehue-Cordón Caulle, Chile (2011), to travel around the pole. For tropical volcanic eruptions, the normal residual stratospheric meridional circulation lifts the sulphate aerosols in the tropics [6], from where they are transported poleward and returned back into the troposphere at higher latitudes on a timescale of 1-2 years [125-127].

The injection height [94] into the atmosphere is a major controlling factor for the residence time of aerosols. Generally, higher injection heights result in higher residence times [128]. However, the amount of aerosols and volcanic ash represents another controlling factor. High stratospheric concentrations of sulphate aerosols do not necessarily persist longer in the stratosphere than moderate concentrations. The higher the stratospheric concentrations of sulphate aerosol particles, the higher the collision rates, which cause larger particle sizes and faster fallout and consequently shorter lifetime of the volcanic aerosols [129]. In the presence of volcanic ash, when sulphate condensation on ash surfaces takes place (see Section 2.4), the atmospheric lifetime of sulphate aerosols is also reduced due to the faster sedimentation of the relatively large ash particles.

During sedimentation in the atmosphere, sulphate aerosols are at or very close to their terminal fall velocities, which are given by the Stokes-Cunningham formula [130]. In the troposphere, washout and rainout represent the major removal processes of sulphate aerosols [131]. Gravitational settling of volcanic ash has often been observed to exceed the terminal fall velocity of single ash particles $[132,133]$. Volcanic ash aggregates consisting of numerous ash particles attached to each other in an ice-ash-mixture or by electrostatic forces explain this behaviour [134-136], which leads to increased sedimentation close to the volcano and reduced atmospheric volcanic ash concentration during long-range transport. However, the scientific knowledge on major aggregation formation processes is still limited $[48,133]$.
Deposition of sulphate and volcanic ash onto ice covered surfaces, into the ocean, on peat, and so forth can be reconstructed from historical archives (namely ice, peat, sea, and ocean sediment), which may provide useful information on past volcanic activity $[137,138]$. High-quality ice core records on acidity as surrogate for volcanic sulphate deposition are restricted to the last 1000-1500 years [32], with decreasing quality as depth is increased. Based on marine sediment core data, reference [37] estimated the millennial scale flux of volcanic ash into the Pacific Ocean to about 128-221 Tg/yr.

\section{Climate Forcing}

4.1. Direct Radiative Effects: Absorption/Scattering of Sunlight/Long-Wave Radiation. When volcanic ash is released into the atmosphere during volcanic eruptions or remobilisation events, it reduces visibility and solar irradiation reaching the earth's surface thereby cooling the earth's surface [139]. The short atmospheric residence time of the majority of volcanic ash restricts its direct radiative effects (and indirect radiative effects, see Section 4.2) to the region close to the eruption and along the major transport pathways in the atmosphere, where, however, the direct radiative effects of volcanic ash may be dominant [48].

However, the major global direct radiative effects after volcanic eruption result from stratospheric sulphate aerosols $[6,31]$. They scatter incoming shortwave solar radiation, thereby, leading to a cooling of the earth's surface and counteracting global warming. Therefore, the injection of sulphate aerosols into the stratosphere is a proposed geoengineering technique $[110,140]$ to counteract global warming, which is however discussed very controversially with respect to technical solutions, costs, efficiency, side effects, and ethical issues [141]. In addition to sulphate aerosols, volcanic ash particles have been observed for several months in the lower stratosphere following major volcanic eruptions [33, 34]. They may become coated with aqueous $\mathrm{H}_{2} \mathrm{SO}_{4}$ and can also contribute to the cooling of the earth's surface. Sulphate aerosols also absorb and emit radiation in the near-infrared spectral range thereby heating the stratosphere [6].

4.2. Indirect Radiative Effects: Cloud Condensation and Ice Nuclei. In the troposphere, volcanic sulphate aerosols and ash can act as cloud condensation nuclei (CCN) and ice nuclei (IN). The increase in cloud droplet number concentrations in the presence of aerosols, which modifies the cloud radiative properties, is referred to as the first indirect effect [142]. The second indirect effect [143] describes the aerosol effect on lifetime and precipitation formation of clouds. Volcanic sulphate aerosol in the troposphere is either formed from volcanic $\mathrm{SO}_{2}$ emissions released into the troposphere or results from downward transport from the stratosphere by sedimentation. In comparison to the direct radiative impact of volcanic sulphate aerosols in the stratosphere, the indirect effect is of minor importance, although it may have considerable local effects, such as the modification of precipitation. An initial suppression of precipitation leads to an increase of liquid water and water vapour staying in the atmosphere, which may 
trigger heavy precipitation events [144]. Therefore, aerosols including volcanic ash and sulphate, which act as CCN [145, 146] and IN (see below), have the potential to affect the earth's radiation budget and the hydrological cycle locally, regionally, or in some cases, globally [147]. In supercooled clouds, the presence of particulate material, such as volcanic ash $[95,148-$ 150], may initiate heterogeneous nucleation of ice crystals at significantly lower supersaturations and higher freezing temperatures than in the case of homogeneous freezing [148]. Atmospheric and volcanic processing including modifications of the surface chemical composition of volcanic ash particles (see Section 2) have implications for their behaviour to act as CCN or IN and to release nutrients (in particular iron) in contact with seawater (see Section 4.4).

4.3. Other Radiation Induced Indirect Climate Effects. The radiative effects of stratospheric sulphate aerosols released in particular from tropical volcanic eruptions (see Section 4.1) trigger several modifications of the global climate system [6], which remain to be fully understood until today. Stratospheric warming caused by volcanic sulphate aerosols decreases the tropopause height [151]. In addition, the poleto-equator temperature gradient in the lower stratosphere is increased [6]. As the circulation in the stratosphere and troposphere is coupled, the polar vortex is strengthened amplifying circulation patterns and creating increased surface temperature during winter in the northern hemisphere. For a detailed description, the reader is referred to [6]. Stratospheric ozone concentrations are reduced by heterogeneous reactions on volcanic sulphate aerosol surfaces. Modifications in sea level height [152], river run-off [153], and tropical precipitation [154] are reported. Additional nonlinear climate feedbacks, for example, between the atmosphere and the ocean heat content and dynamics [155] or the terrestrial vegetation [156] are assumed to modify atmospheric $\mathrm{CO}_{2}$. However, due to the complexity of the climate system, it still remains open if modifications in the global carbon cycle after volcanic eruptions can fully be explained with radiation induced effects after volcanic eruptions. As the last three major topical volcanic eruptions (Agung, 1963; El Chichón, 1982; Pinatubo, 1991) coincided with substantial El Niño events, it has been proven difficult to separate climate response due to El Niño, volcanic forcing, or the combined effect [157].

4.4. Iron Fertilisation of the Surface Ocean. Many biological functions in marine plankton depend on trace metals that are scarce in the ocean but that are contained in volcanic ash. Especially, iron is required for many important oceanic biogeochemical processes such as cellular processes, photosynthesis, respiration, nitrogen fixation, and nitrate reduction. In High-Nutrient-Low-Chlorophyll (HNLC) ocean waters [158] (Southern Ocean and northern and equatorial Pacific), iron represents the major limiting component for marine primary production (MPP). This "iron hypothesis" was introduced by [159]. Iron supply to these ocean waters affects MPP and phytoplankton growth, which in turn influences the development of higher trophic levels of the marine food chain. The biological $\mathrm{CO}_{2}$ pump of the ocean is stimulated due to the build-up of organic carbon in the surface ocean and descend to the deeper ocean. Thereby atmospheric $\mathrm{CO}_{2}$ is reduced. Finally, a reduction of atmospheric $\mathrm{CO}_{2}$ concentrations is triggered as the surface ocean $\mathrm{CO}_{2}$ concentration reequilibrates with the atmospheric $\mathrm{CO}_{2}$ concentration. Today, the effects of ocean iron fertilisation on the global carbon cycle are discussed controversially, specifically, in the context of climate engineering.

During the past few years, several studies highlighted the influence of volcanic ash on the biogeochemistry of the surface ocean [35-39] via the dissolution of trace species, in particular iron compounds, in water $[85,160]$. Beside iron compounds, volcanic ash can release additional trace metal salts containing, for example, copper and zinc, which are known for their fertilising as well as toxic effects on plankton [38].

According to [37], volcanic ash deposition fluxes to the Pacific Ocean are comparable to the mineral dust flux into the Pacific Ocean of $\sim 100 \mathrm{Tg} / \mathrm{yr}$ [161]. Yearly mineral dust deposition into the ocean may, however, be well below the deposition of volcanic ash during major volcanic eruptions. During and after the eruption of Mt. Hudson in Chile (August 12-15, 1991), the ocean iron deposition connected to volcanic ash corresponds to about 500 years of iron deposition connected to mineral dust from Patagonia [162]. For a detailed comparison of volcanic ash versus mineral dust environmental and climate effects see [48].

Another effect on climate induced by ocean iron fertilisation is associated with a potentially increased flux of organic carbon (OC) containing sea-spray aerosols [163] and dimethyl sulphide (DMS) [164], which may be oxidised to sulphate aerosols. Sulphate and OC aerosols may form CCN's contributing to the indirect aerosol effects ([165]; see Section 4.2).

\subsection{Climate Effects of Volcanic Sulphate versus Volcanic Ash}

4.5.1. Effect on Atmospheric $\mathrm{CO}_{2}$. Due to backscattering of solar radiation to space, volcanic sulphate aerosols can counteract the global temperature increase, which is driven by the increasing atmospheric load of greenhouse gases. Therefore, artificially injected sulphate aerosols into the stratosphere have been proposed as one possibility of climate engineering, also called geoengineering ("the deliberate change of the earth's climate by mankind"). Although, theoretical studies show that it is possible to cool the earth [110], it is unlikely that the climate system will return to the state prior to humaninduced $\mathrm{CO}_{2}$ increase. In addition, unwished side effects cannot be excluded. It is also clear that this geoengineering method will not reduce $\mathrm{CO}_{2}$ uptake by the ocean and ocean acidification [166], as atmospheric $\mathrm{CO}_{2}$ concentrations are not directly affected. However, indirect effects on the atmospheric carbon cycle, for example, more $\mathrm{CO}_{2}$ uptake by vegetation [156] due to increased diffuse radiation [167], are discussed in the literature.

Another technique of geoengineering is ocean fertilisation by iron. Although several issues concerning the 
efficiency of the biological carbon pump of the ocean are in discussion [158], this method is supposed to counteract global warming by reducing atmospheric $\mathrm{CO}_{2}$ thereby preventing ocean acidification. Beside mineral dust, volcanic ash represents a natural iron fertiliser of the ocean. Reference [158] explains only $25 \%$ of the observed $\mathrm{CO}_{2}$ decrease during glacial maxima with ocean iron fertilisation by mineral dust. Ocean fertilisation by volcanic ash and the subsequently enhanced efficiency of the biological carbon pump provide an additional explanation for the decrease in atmospheric $\mathrm{CO}_{2}$ during the geological past [168]. The following subsections contrast climate forcing by ocean iron-fertilisation with volcanic ash with climate forcing by radiation-induced effects of volcanic sulphate.

\subsubsection{Specific Eruptions}

(a) Kasatochi, Alaska, August 2008, VEI $4\left(52.2^{\circ} \mathrm{N}, 175.5^{\circ} \mathrm{W}\right)$. The volcano Kasatochi on the Aleutian Islands erupted in August 2008. Shortly after this eruption an unusual phytoplankton growth was observed in the NE Pacific [36, 4244]. Seawater $\mathrm{CO}_{2}$ partial pressure at the ocean station Papa decreased by about $40 \mathrm{ppm}$. This textbook example of the development of a massive and large-scale phytoplankton bloom represents the first direct proof of the potential of volcanic ash to fertilise the surface ocean. Two years later, a discussion on the linkage between increased sockeye salmon population in the Fraser River in Canada and ocean iron fertilisation by volcanic ash from Kasatochi started [169-171].

The total volcanic ash flux released from Kasatochi is estimated by 0.2-0.3 km³ DRE (Dense Rock Equivalent) [92]. In comparison with major volcanic eruptions (see below) Kasatochi ash emissions are relatively low. According to [42], the stimulation of the biological $\mathrm{CO}_{2}$ pump by the iron fertilisation with volcanic ash from Kasatochi results in a reduction of atmospheric $\mathrm{CO}_{2}$ by about $0.01 \mathrm{Pg} \mathrm{C}$. This amount of carbon sequestration represents a negligible fraction compared to rise of $\mathrm{CO}_{2}$ emissions resulting from fossil fuel combustion (7-9 Pg C/yr; [172]).

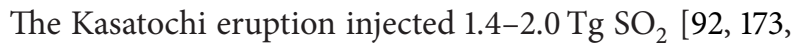
174] into the lower stratosphere. The development of a stable stratospheric sulphate aerosol layer between 15 and $21 \mathrm{~km}$ at mid to high northern latitudes took place within 4-6 weeks after the eruption [173]. Maximum AOD (Aerosol Optical Depth) at $750 \mathrm{~nm}$ was approximately a factor of two above the background value and eventually returned to background levels by March 2009. Although the $\mathrm{SO}_{2}$ injection into the stratosphere by the Kasatochi eruption represents the largest volcanic injection of $\mathrm{SO}_{2}$ into the stratosphere since 1991 and the strength of the eruption is characterised by VEI $=4$, the eruption of Kasatochi in August 2008 caused negligible climate effects due to stratospheric sulphate [175] and ocean fertilisation [42].

(b) Mt. Hudson, Chile, August 1991, VEI $4\left(45.9^{\circ} \mathrm{S}, 72.9^{\circ} \mathrm{W}\right)$. The volcanic eruption of Mt. Hudson took place in August 1991, only two months after the eruption of Pinatubo in June
1991 (see below). Therefore, climate effects associated with the Mt. Hudson eruption are nearly always assessed together with those of the stronger Pinatubo eruption, but often as a minor side effect. Approximately $1.1 \mathrm{~km}^{3}$ of ash was directly supplied to the iron-limited Atlantic sector of the Southern Ocean [176]. Ash fallout was also recorded on the Falkland Islands $(\sim 1.000 \mathrm{~km}$ SE from the volcano; [177]) and South Georgia ( $\sim 2.700 \mathrm{~km}$ SE from the volcano; [178]). This ash deposition into the ocean-although it considerably exceeds the possible amount of ash from Pinatubo that was potentially deposited in the Southern Ocean-has never before been taken into account as an explanation for the decrease in atmospheric $\mathrm{CO}_{2}$ concentration of 1-2 ppm after 1991 [40]. The global climate in 1991 was also influenced by an El Niño event [157]. The usual increase in atmospheric $\mathrm{CO}_{2}$ concentrations during El Niño events, however, did not take place in 1991 [179]. The reasons are hidden in the until today not fully understood nonlinear climate feedbacks after major volcanic eruptions (see Section 4.3). Most probably, the direct fertilisation effect of the ocean by iron with Mt. Hudson ash was partly inhibited by the absence of sunlight during southern hemispheric winter. However, after the Mt. Hudson eruption about $1.6 \mathrm{~km}^{3}$ DRE was deposited in Patagonia. The dry and windy conditions in this region cause efficient remobilisation of the ash into the atmosphere [12]. When transported towards the ocean, this ash is eventually available for ocean fertilisation. As satellite ocean colour data are only randomly available before 1997 (http://oceancolor.gsfc.nasa.gov), coupled biogeochemical ocean-atmosphere modelling or the analysis of the young parts of historical archives like peat cores or lake sediments located downstream of Mt. Hudson may shed some light on such a hypothesis. The Falkland Islands located about $1500 \mathrm{~km}$ southeast from Patagonia in the downstream direction offer ideal conditions for peat accumulation and analysis of volcanic ash in peat $[180,181]$.

During the Mt. Hudson eruption, the injected amount of $\mathrm{SO}_{2}$ into the stratosphere was similar to the Kasatochi eruption (1.65 $\left.\mathrm{Tg} \mathrm{SO}_{2} ;[124]\right)$. The southern hemispheric AOD in higher latitudes from August 23 until September 30 clearly indicates the stratospheric sulphate originated from Mt. Hudson (Figure 3). Through Lidar and satellite measurements over Antarctica, the Mt. Hudson sulphate cloud was observed between 9 and $13 \mathrm{~km}$ within the polar vortex from August to October 1991 [182, 183]. However, the Mt. Hudson stratospheric sulphate load and the subsequent global climate forcing by reduced solar irradiation can only be partly separated from the higher stratospheric sulphate loading produced from the Pinatubo eruption (Figure 3). Therefore, for climate effects induced from the stratospheric sulphate load, see the discussion below associated with the Pinatubo eruption.

(c) Mt. Pinatubo, Philippines, June 1991, VEI $6\left(15.1^{\circ} \mathrm{N}\right.$, $120.3^{\circ} \mathrm{E}$ ). The Pinatubo eruption represents one of the largest $\mathrm{SO}_{2}$ injections into the stratosphere since the beginning of the 20th century with approximately $20 \mathrm{Tg} \mathrm{SO}$ [122]. After the eruption, a global average cooling of $0.4 \mathrm{~K}$ occurred at the earth surface $[172,184,185]$ and an increase in 
SAGE II $1020 \mathrm{~nm}$ optical depth

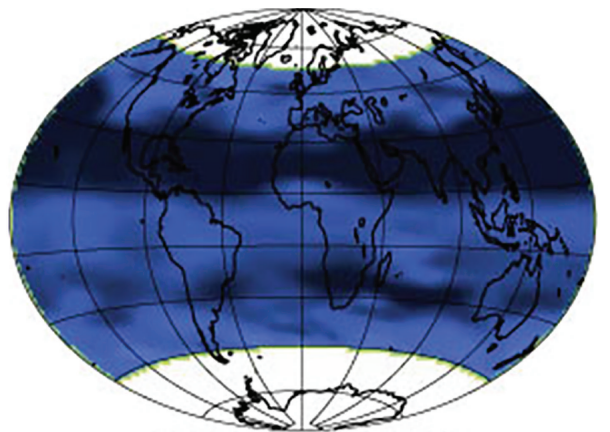

April 10, 1991 to May 13, 1991

(a)

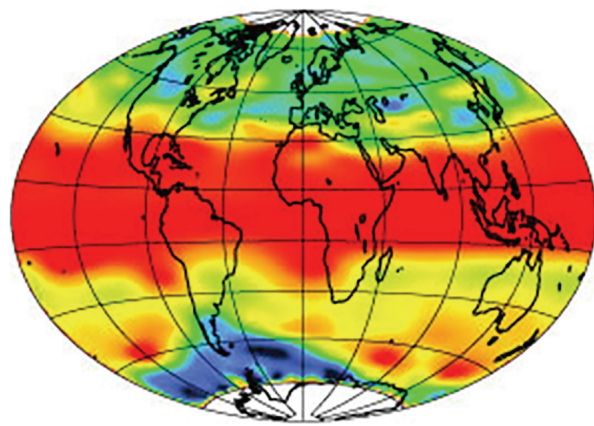

August 23, 1991 to September 30, 1991

(c)

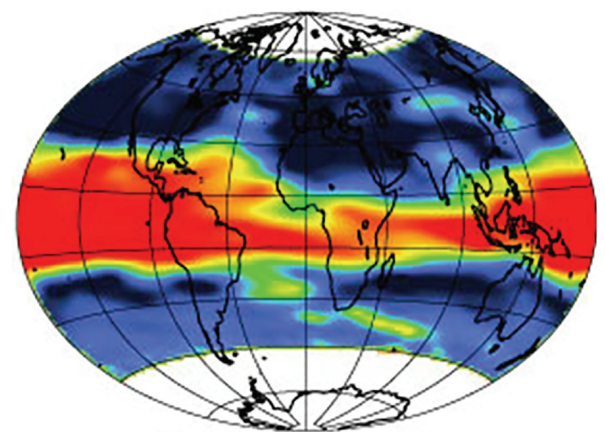

June 15,1991 to July 25,1991

(b)

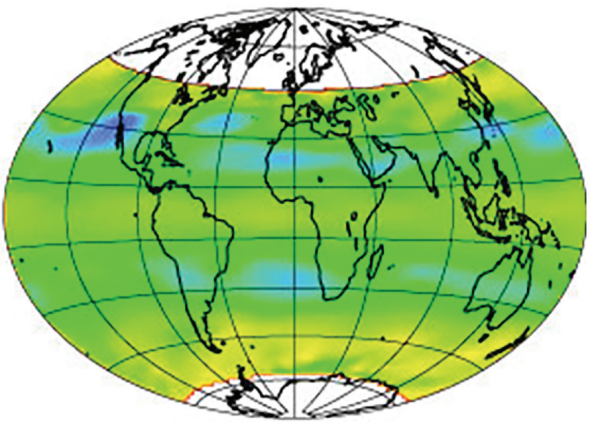

December 5, 1993 to January 16, 1994

(d)

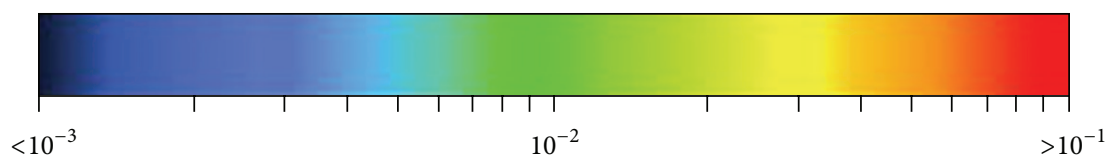

Figure 3: Aerosol optical depth. Eruption of Pinatubo: June 15, 1991; eruption of Mt. Hudson: August 15, 1991 (Courtesy of NASA).

stratospheric temperatures of $2-3 \mathrm{~K}$ was observed [186]. The direct radiation at the Mauna Loa observatory on Hawaii was reduced by $\sim 140 \mathrm{~W} / \mathrm{m}^{2}$, whereas diffuse radiation increased by $\sim 100 \mathrm{~W} / \mathrm{m}^{2}$ [6]. Also, reduced atmospheric $\mathrm{CO}_{2}$ concentrations of around 1-2 ppm were observed [40]. Reference [156] argued that this was a consequence of increased vegetation photosynthesis due to diffuse radiation induced by the presence of the volcanic sulphate aerosol layer in the atmosphere. References [40,41] suggested that the atmospheric $\mathrm{CO}_{2}$ drawdown was the result of ocean fertilisation by Pinatubo ash, which reached the Southern Ocean by November 1991. However, the majority of the volcanic ash released during the 1991 Pinatubo eruption (5$6 \mathrm{~km}^{3}$ DRE; [91]) was deposited in or nearby the South China Sea [187]. Only a few percent reached the ironlimited Southern Ocean. Therefore, it is more likely that a climate effect by ocean fertilising within the Southern Ocean is negligible. However, as outlined above, Southern Ocean fertilisation by volcanic ash from the Mt. Hudson eruption needs further investigations. By taking into account the radiative effect of stratospheric sulphate from volcanic origin only, indirect effects on the climate system cannot fully be explained, for example, by global climate model simulations [188] in particular after the 1991 Pinatubo eruption. However, it remains open, if yet unknown feedback mechanisms in the climate system or unconsidered processes, such as the ocean fertilisation by volcanic ash with iron, may offer satisfactory explanations.

(d) Mt. Katmai, Alaska, June 1912, VEI $6\left(58.2^{\circ} \mathrm{N}, 154.9^{\circ} \mathrm{W}\right)$. The world's largest volcanic eruption of the 20th century took place at Novarupta, Alaska. Most of the magma vented at Novarupta was stored beneath Mt. Katmai, therefore, both names appear in the literature. During the eruption, about $13 \mathrm{~km}^{3}$ DRE of volcanic ash [189] and $5 \mathrm{Tg} \mathrm{SO} \mathrm{SO}_{2}$ [190] were injected into the atmosphere. The volcanic ash cloud was transported to west-south-west directions with ash fall over the Gulf of Alaska and Northern America [191]. According to 
[44], ocean fertilisation of the NE Pacific during the month of June has the potential to increase phytoplankton concentrations thereby stimulating the ocean biological pump, which reduces atmospheric $\mathrm{CO}_{2}$ concentrations. Phytoplankton production in the NE Pacific is even more efficient from July until October [44] if iron is supplied to the ocean. According to [191], the loose volcanic ash deposits around Katmai produced ash clouds throughout the summer of 1912 through remobilisation by wind thereby providing further iron for the fertilization of the NE Pacific Ocean. But, as time goes by, repeated rainfall in the depositional area may diminish the iron contained in the surface rim of volcanic ash through leaching. Many kilometres long pumice rafts released from the Katmai eruption have been observed in the coastal waters of the Gulf of Alaska even decades after the Katmai eruption [188], which can supply iron for the fertilisation of the ocean as well [192]. However, as the area of the NE Pacific that may have been fertilised with iron from the volcanic ash and pumice released form Mt. Katmai is much smaller than that after the Kasatochi eruption in 2008 $[36,92,191]$, a climate effect induced by ocean fertilisation is probably negligible. In addition, the radiative effect due to volcanic sulphate from Mt. Katmai was restricted to the Northern Hemisphere [190] and has therefore limited global climate effects as well.

(e) Huaynaputina, Peru, February 1600, VEI 6 (16.6 S, $70.8^{\circ} \mathrm{W}$ ). The eruption of Huaynaputina volcano in Peru in February $1600 \mathrm{AD}$ was the largest historically recorded eruption in South America with a VEI of 6 and globally one of the largest events during the past 2000 years. The eruption produced more than $9.6 \mathrm{~km}^{3}$ DRE of volcanic ash [193]. Ash fallout was reported throughout southern Peru, northern Chile, and western Bolivia and is also known to have settled into the tropical Pacific as well as the Southern Ocean, two large HNLC areas. Volcanic ash particles from the Huaynaputina eruption have been identified in Antarctic ice cores [194], thereby, confirming the large-scale transport of volcanic ash from the Huaynaputina eruption to the Southern Ocean. Numerical model studies of volcanic ash dispersion and deposition after the eruption of Huaynaputina in 1600 will be necessary during typical climate conditions such as $\mathrm{El}$ Niño and La Niña and normal years to reconstruct the major depositional areas and fluxes into the ocean. This should be followed by ocean biogeochemical modelling in order to determine the ocean biogeochemical response on fertilisation by Huaynaputina volcanic ash. An iron-fertilisation effect may partly explain the $10 \mathrm{ppm}$ decrease in atmospheric $\mathrm{CO}_{2}$ concentration measured in Antarctic ice cores after 1600 [195]. However, as no $\delta^{13} \mathrm{CO}_{2}$ measurements are available, [195] conclude that it is unclear whether the initial $\mathrm{CO}_{2}$ decrease at $\mathrm{AD} 1600$ was driven by changes in the carbon exchange rates between the atmosphere and the ocean or the terrestrial biosphere.

Reference [196] reports that the most severe cooling of $-0.81 \mathrm{~K}$ in the Northern Hemisphere during the past 600 years occurred in 1601. The authors speculate if in addition to the Huaynaputina eruption a yet unidentified eruption occurred at the same time or if the climate effect of the Huaynaputina eruption has been greatly underestimated. This is because the cooling is greater than is suggested by the degree of acidity in the various ice core records from which the stratospheric sulphate load is determined. Reference [193] estimates a global stratospheric loading of $\sim 70 \mathrm{Tg} \mathrm{H}_{2} \mathrm{SO}_{4}$ due to the Huaynaputina eruption based on ice core data, whereas [197] reports $\sim 80-170 \mathrm{Tg} \mathrm{H}_{2} \mathrm{SO}_{4}$ based on petrological analysis. These estimates greatly exceed the stratospheric $\mathrm{H}_{2} \mathrm{SO}_{4}$ load after the 1991 Pinatubo eruption $\left(\sim 30 \mathrm{Tg} \mathrm{H}_{2} \mathrm{SO}_{4}\right.$; [16]). Due to the high uncertainties connected with the stratospheric sulphate loading and with indirect effects of reduced solar irradiation (see Section 4.3), a climate effect induced by volcanic ash ocean fertilisation can neither be confirmed nor excluded. Climate modelling studies including the volcanic ash ocean fertilisation effect may shed more light on the relevant processes affecting climate after major volcanic eruptions.

4.5.3. Geological Records. Many reasons for millennial climate change have been discussed in the literature, for example, tectonic motion, orbital variations, modifications in cosmic ray fluxes, silicate weathering in orogens, and volcanism [168]. Until recently, the discussion of volcanic forcing on climate on geologic timescales was restricted to radiative effects of stratospheric sulphate and further indirect effects (see Section 4.3; [198]). Although the occurrence of volcanic glass in deep-sea sediments has been regarded as indicator for volcanic activity, [199] did not consider ocean fertilisation by volcanic ash as a trigger for millennial climate change. However, it still remains unclear if even a megavolcanic eruption may trigger climate cooling on at least century timescale solely through radiative effects of stratospheric sulphate. The most recent major ignimbrite eruption was at Toba, Sumatra, about $75 \mathrm{ka}$ ago. Toba erupted $\sim 2500 \mathrm{~km}^{3}$ DRE [200]. Cooling related to the Toba eruption lasted about 1000 years [200]; however, recent studies suggest a weaker temperature response [201]. There is ongoing discussion about the stratospheric sulphate burden, its residence time, and climate forcing. Although much of the Toba ash was deposited in the Bay of Bengal [202], today an area in which marine primary productivity is not limited by the availability of iron, ocean iron fertilisation has not yet been considered to contribute to climate variability after the Toba eruption.

By analysing Antarctic ice cores on millennial time periods, [203] concluded that in addition to the volcanic sulphate effects on planetary albedo, volcanic ash may increase soluble iron in large surface areas of the nutrient limited Southern Ocean thereby stimulating growth of phytoplankton and affecting the global carbon cycle. These two effects together are supposed to trigger cooling during the last millennium [203]. Also [168, 204] present geochronologic and biogeochemical data suggesting that iron fertilisation by volcanic ash provides a plausible mechanism for atmospheric $\mathrm{CO}_{2}$ drawdown during the Cenozoic climatic transition (about $33.5 \mathrm{Ma}$ ago, near the Eocene-Oligocene boundary, when major continental glaciation in Antarctica began), both in terms of timing and biogeochemical mass balance. 
Iron fertilisation by repeated ignimbrite eruptions may have accelerated the global cooling by the stepwise forcing of the climate across a climatic threshold, via the cumulative effect of $\mathrm{CO}_{2}$ drawdown by hundreds of volcanic fertilisation events (note that the distribution of HNLC areas in ancient oceans was probably different form today, but remains poorly understood). This hypothesis suggests that repeated episodes of oceanic iron fertilisation by great volumes of rhyolitic ash might be sufficient to initiate cold climatic modes. Other studies also suggesting that the positive carbon isotopic anomaly near the Eocene-Oligocene boundary can be interpreted by record enhanced marine production and burial of organic carbon that led to decreased atmospheric $\mathrm{CO}_{2}$ and global cooling are published by, for example, references [205207]. This explanation is also proposed for the Cretaceous Ocean Anoxic Event 2 (about 94 million years ago; [208]) and for the younger Northern Hemispheric glaciation (about 2.75 million years ago; [209]). Reference [210] presented a close correlation between iron input and marine export production for the sub-Antarctic Atlantic based on a multi-proxy dataset from marine sediment cores for the last 1.1 million years. Their results imply that the process of ion fertilisation on marine biota was a recurring process operating in the subAntarctic region over the glacial/interglacial cycles. Mineral dust is made responsible for a $\mathrm{CO}_{2}$ decrease of $25 \%$ during the last glacial maxima [158]. An overall assessment of the role of volcanic ash fertilisation of the ocean on atmospheric $\mathrm{CO}_{2}$ on geological timescales in comparison to mineral dust effects will be necessary to increase our understanding of the processes contributing to natural climate variability.

\section{Outlook}

After the recent major volcanic eruptions like El Chichón (1982) or Pinatubo (1991), ground-based and satellite based observations of the volcanic stratospheric sulphate burden and distribution as well as, for example, modifications in atmospheric $\mathrm{CO}_{2}$, solar radiation, and atmospheric temperature are available. These clearly reveal the importance of volcanic stratospheric sulphate in cooling the earth surface, which induces a number of further indirect effects on climate via nonlinear reaction and feedbacks in the climate system (see Section 4.3; [6]). Thereby, the earlier belief that volcanic ash particles suspended in the atmosphere are responsible for volcanic climate forcing [24] has been revised [2] and climate impacts induced by volcanic ash were no longer in the focus of research. Most of the interpretations of the climate effects after volcanic eruptions are based on climate model simulations driven by stratospheric volcanic sulphate forcing. However, until now, global climate models have difficulties to reproduce the observed variability of the earth system after large volcanic eruptions [188]. Either important feedback mechanisms have been overseen or still missing processes like ocean fertilisation by volcanic ash have not been taken into account. Therefore, it will be necessary to reinvestigate historical volcanic eruptions and their climate impact including the oceanic iron-fertilisation potential of volcanic ash. This is dependent on the geographical location of an erupting volcano, the amount of volcanic ash deposited into the ocean directly after an eruption or posteruptive through remobilisation of ash form deposits, the availability of macronutrient, and micronutrient in the adjacent ocean areas and the atmospheric conditions.

Generally, the largely overseen aspect of volcanic induced climate variability by ocean fertilisation urgently needs to be better assessed. This also holds for the role of volcanic ash fertilisation of the ocean in comparison with mineral dust ocean fertilisation [48] to better understand natural climate variability on geological timescales. Therefore, this review intends to trigger interdisciplinary investigations involving ocean biogeochemistry and biology, volcanology, geochemistry, meteorology, atmospheric chemistry, and climate research groups. To increase our current understanding of the volcanic ash fertilisation potential of the surface ocean, it will be necessary to achieve further knowledge about the iron processing in volcanic plumes and during long-range transport by conducting modelling studies and measurements in the field and laboratory. In addition, it is necessary to clarify how volcanic ash, as a so far neglected constituent in the marine environment, influences marine productivity and species composition, two main factors that affect marine carbon cycling and thus global climate.

\section{Conflict of Interests}

The author declares that there is no conflict of interests regarding the publication of this paper.

\section{Acknowledgments}

The author acknowledges the financial support through the Cluster of Excellence "CliSAP" (EXC177), University of Hamburg, funded through the German Science Foundation (DFG). The author thanks Michael Hemming, Matthias Hort, and Klemen Zakšek for their comments on the paper.

\section{References}

[1] R. Sparks, M. Bursik, J. Gilbert, L. Glaze, H. Sigurdsson, and A. Woods, Volcanic Plumes, John Wiley \& Sons, Chichester, UK, 1997.

[2] H.-U. Schmincke, Volcanism, Springer, Berlin, Germany, 2004.

[3] W. I. Rose and A. J. Durant, "Fine ash content of explosive eruptions," Journal of Volcanology and Geothermal Research, vol. 186, no. 1-2, pp. 32-39, 2009.

[4] B. Zimanowski, K. Wohletz, P. Dellino, and R. Büttner, "The volcanic ash problem," Journal of Volcanology and Geothermal Research, vol. 122, no. 1-2, pp. 1-5, 2003.

[5] R. B. Symonds, W. I. Rose, G. J. S. Bluth, and T. M. Gerlach, "Volcanic gas studies: methods, results and applications," in Volatiles in Magma, M. R. Caroll and J. R. Holloway, Eds., vol. 30 of Reviews in Mineralogy and Geochemistry, pp. 1-66, 1994.

[6] A. Robock, "Volcanic eruptions and climate," Reviews of Geophysics, vol. 38, no. 2, pp. 191-219, 2000.

[7] P. M. Ayris, A. F. Lee, K. Wilson, U. Kueppers, D. B. Dingwell, and P. Delmelle, " $\mathrm{SO}_{2}$ sequestration in large volcanic eruptions: 
high-temperature scavenging by tephra," Geochimica et Cosmochimica Acta, vol. 110, no. 1, pp. 58-69, 2013.

[8] G. Hoshyaripour, Modulation of ash iron solubility in volcanic eruption plumes [Ph.D. thesis], University of Hamburg, Hamburg, Germany, 2013.

[9] A. Aiuppa, A. Franco, R. von Glasow et al., "The tropospheric processing of acidic gases and hydrogen sulphide in volcanic gas plumes as inferred from field and model investigations," Atmospheric Chemistry and Physics, vol. 7, no. 5, pp. 1441-1450, 2007.

[10] P. V. Hobbs, D. A. Hegg, and L. F. Radke, "Resuspension of volcanic ash from Mount St. Helens," Geophysical Research Letters, vol. 88, pp. 3919-3921, 1983.

[11] D. Hadley, G. L. Hufford, and J. J. Simpson, "Resuspension of relic volcanic ash and dust from Katmai: still an aviation hazard," Weather and Forecasting, vol. 19, pp. 829-840, 2004.

[12] T. M. Wilson, J. W. Cole, C. Stewart, S. J. Cronin, and D. M. Johnston, "Ash storms: impacts of wind-remobilised volcanic ash on rural communities and agriculture following the 1991 Hudson eruption, Chile," Bulletin of Volcanology, vol. 73, no. 3, pp. 223-239, 2011.

[13] S. J. Leadbetter, M. C. Hort, S. von Löwi, K. Weber, and C. S. Witham, "Modeling the resuspension of ash deposited during the eruption of Eyjafjallajökull in spring 2010," Journal of Geophysical Research, vol. 117, no. 20, 2012.

[14] T. Thorsteinsson, G. Gísladóttir, J. Bullard, and G. McTainsh, "Dust storm contributions to airborne particulate matter in Reykjavík, Iceland," Atmospheric Environment, vol. 45, no. 32, pp. 5924-5933, 2011.

[15] T. Thorsteinsson, T. Jóhannsson, A. Stohl, and N. I. Kristiansen, "High levels of particulate matter in Iceland due to direct ash emissions by the Eyjafjallajökull eruption and resuspension of deposited ash," Journal of Geophysical Research, vol. 117, no. 9, 2012.

[16] M. P. McCormick, L. W. Thomason, and C. R. Trepte, "Atmospheric effects of the Mt Pinatubo eruption," Nature, vol. 373, no. 6513, pp. 399-404, 1995.

[17] J. B. Pollack, O. B. Toon, C. Sagan, A. Summers, B. Baldwin, and W. van Camp, "C. G. Newhall, and S. Self, "The volcanic exposivity idex (VEI) — an estimate of explosive magnitude for historical volcanism," Journal of Geophysical Research, vol. 81, pp. 1071-1083, 1976.

[18] C. G. Newhall and S. Self, "The volcanic explosivity index (VEI) - an estimate of explosive magnitude for historical volcanism," Journal of Geophysical Research, vol. 87, no. 2, pp. 1231$1238,1982$.

[19] M. R. Rampino and S. Self, "Sulphur-rich volcanic eruptions and stratospheric aerosols," Nature, vol. 310, no. 5979, pp. 677679, 1984.

[20] J. F. Luhr, I. S. E. Carmichael, and J. C. Varekamp, “The 1982 eruptions of El Chichón volcano, Chiapas, Mexico: mineralogy and petrology of the anhydritebearing pumices," Journal of Volcanology and Geothermal Research, vol. 23, no. 1-2, pp. 69108, 1984.

[21] M. M. Halmer, H.-U. Schmincke, and H.-F. Graf, “The annual volcanic gas input into the atmosphere, in particular into the stratosphere: a global data set for the past 100 years," Journal of Volcanology and Geothermal Research, vol. 115, no. 3-4, pp. 511$528,2002$.

[22] A. Aiuppa, S. Inguaggiato, A. J. S. McGonigle et al., " $\mathrm{H}_{2} \mathrm{~S}$ fluxes from Mt. Etna, Stromboli, and Vulcano (Italy) and implications for the sulfur budget at volcanoes," Geochimica et Cosmochimica Acta, vol. 69, no. 7, pp. 1861-1871, 2005.

[23] L. Clarisse, P.-F. Coheur, S. Chefdeville, J.-L. Lacour, D. Hurtmans, and C. Clerbaux, "Infrared satellite observations of hydrogen sulfide in the volcanic plume of the August 2008 Kasatochi eruption," Geophysical Research Letters, vol. 38, no. 10, 2011.

[24] H. H. Lamb, "Volcanic dust in the atmosphere, with a chronology and assessment of its meteorological significance," Philosophical Transactions of the Royal Society A, vol. 266, no. 1178, pp. 425-533, 1970.

[25] O. B. Toon and J. B. Pollack, "Atmospheric aerosols and climate," American Scientist, vol. 68, no. 3, pp. 268-278, 1980.

[26] K. Y. Kondratyev, "Volcanoes and climate," WCP-54 WMO/TD166, World Meteorological Organization, Geneva, Switzerland, 1988.

[27] A. Robock, "Volcanoes and climate," in Climate and GeoSciences: A Challenge for Science and Society in the 21st Century, vol. 285 of NATO ASI Series C, pp. 309-314, 1989.

[28] A. Robock, "The volcanic contribution to climate change of the past 100 years," in Greenhouse-Gas-Induced Climatic Change: A Critical Appraisal of Simulations and Observations, M. E. Schlesinger, Ed., pp. 429-444, Elsevier Sciences, New York, NY, USA, 1991.

[29] K. Y. Kondratyev and I. Galindo, Volcanic Activity and Climate, A. Deepak, Hampton, Va, USA, 1997.

[30] G. A. Zielinski, "Use of paleo-records in determining variability within the volcanism-climate system," Quaternary Science Reviews, vol. 19, no. 1-5, pp. 417-438, 2000.

[31] C. Textor, H.-F. Graf, C. Timmreck, and A. Robock, "Emissions from volcanoes," in Emissions of Chemical Compounds and Aerosols in the Atmosphere, C. Granier, C. Reeves, and P. Artaxo, Eds., vol. 18 of Advances in Global Change Research, pp. 269-303, Kluwer, Dordrecht, The Netherlands, 2004.

[32] J. Cole-Dai, "Volcanoes and climate," Wiley Interdisciplinary Reviews, vol. 1, no. 6, pp. 824-839, 2010.

[33] R. F. Pueschel, P. B. Russell, D. A. Allen et al., "Physical and optical properties of the Pinatubo volcanic areosol: aircraft observations with impactors and a Sun-tracking photometer," Journal of Geophysical Research, vol. 99, no. 6, pp. 12915-12922, 1994.

[34] P. B. Russell, J. M. Livingston, R. F. Pueschel et al., "Global to microscale evolution of the Pinatubo volcanic aerosol derived from diverse measurements and analyses," Journal of Geophysical Research, vol. 101, no. 13, pp. 18745-18763, 1996.

[35] S. Duggen, P. Croot, U. Schacht, and L. Hoffmann, "Subduction zone volcanic ash can fertilize the surface ocean and stimulate phytoplankton growth: evidence from biogeochemical experiments and satellite data," Geophysical Research Letters, vol. 34, no. $1,2007$.

[36] B. Langmann, K. Zakšek, M. Hort, and S. Duggen, "Volcanic ash as fertiliser for the surface ocean," Atmospheric Chemistry and Physics, vol. 10, no. 8, pp. 3891-3899, 2010.

[37] N. Olgun, S. Duggen, P. L. Croot et al., "Surface ocean iron fertilization: the role of airborne volcanic ash from subduction zone and hot spot volcanoes and related iron fluxes into the Pacific Ocean," Global Biogeochemical Cycles, vol. 25, no. 4, 2011.

[38] L. J. Hoffmann, E. Breitbarth, M. V. Ardelan et al., "Influence of trace metal release from volcanic ash on growth of Thalassiosira pseudonana and Emiliania huxleyi," Marine Chemistry, vol. 132133, pp. 28-33, 2012. 
[39] E. P. Achterberg, C. M. Moore, A. Henson et al., "Natural iron fertilization by the Eyjafjallajökull volcanic eruption," Geophysical Research Letters, vol. 40, no. 5, pp. 921-926, 2013.

[40] J. L. Sarmiento, “Atmospheric $\mathrm{CO}_{2}$ stalled," Nature, vol. 365, no. 6448, pp. 697-698, 1993.

[41] A. J. Watson, "Volcanic $\mathrm{Fe}, \mathrm{CO}_{2}$, ocean productivity and climate," Nature, vol. 385, no. 6617, pp. 587-588, 1997.

[42] R. C. Hamme, P. W. Webley, W. R. Crawford et al., "Volcanic ash fuels anomalous plankton bloom in subarctic Northeast Pacific," Geophysical Research Letters, vol. 37, no. 19, 2010.

[43] D. Lockwood, P. D. Quay, M. T. Kavanaugh, L. W. Juranek, and R. A. Feely, "High-resolution estimates of net community production and air-sea $\mathrm{CO}_{2}$ flux in the Northeast Pacific," Global Biogeochemical Cycles, vol. 26, no. 4, 2012.

[44] A. Lindenthal, B. Langmann, J. Paetsch, I. Lorkorwski, and M. Hort, "The ocean response to volcanic iron fertilization after the eruption of Kasatochi volcano: a regional biogeochemical model study," Biogeosciences, vol. 10, pp. 3715-3729, 2013.

[45] T. D. Jickells, Z. S. An, K. K. Andersen et al., "Global iron connections between desert dust, ocean biogeochemistry, and climate," Science, vol. 308, no. 5718, pp. 67-71, 2005.

[46] T. Simkin and I. Siebert, Volcanoes of the World, Smithonian Institution, Geoscience Press, Misoula, Mont, USA, 1994.

[47] T. A. Mather, D. M. Pyle, and C. Oppenheimer, "Tropospheric volcanic aerosol," in Volcanism and the Earth's Atmosphere, vol. 139 of Geophysical Monograph, pp. 89-211, 2003.

[48] B. Langmann, "Volcanic ash versus mineral dust: atmospheric processing and environmental and climate impacts," ISRN Atmospheric Sciences, vol. 2013, Article ID 245076, 17 pages, 2013.

[49] H.-F. Graf, J. Feichter, and B. Langmann, "Volcanic sulfur emissions: estimates of source strength and its contribution to the global sulfate distribution," Journal of Geophysical Research, vol. 102, no. 9, pp. 10727-10738, 1997.

[50] G. Heiken, "Morphology and petrography of volcanic ashes," Geological Society of America Bulletin, vol. 83, no. 7, pp. 19611988, 1972.

[51] G. K. Bayhurst, K. H. Wohletz, and A. S. Mason, "A method for characterising volcanic ash from the December 5, 1989, eruption of Redoubt volcano, Alaska," in Proceedings of the 1st International Symposium on Volcanic Ash and Aviation Safety, Chapter A Method for Characterizing Volcanic Ash, vol. 2074 of USGS Bulletin, pp. 13-17, 1991.

[52] M. Nakagawa and T. Ohba, "Minerals in volcanic ash 1: primary minerals and volcanic glass," Global Environmental Research, vol. 6, pp. 41-51, 2003.

[53] A. Belousov, M. Belousova, and B. Voight, "Multiple edifice failures, debris avalanches and associated eruptions in the Holocene history of Shiveluch volcano, Kamchatka, Russia," Bulletin of Volcanology, vol. 61, no. 5, pp. 324-342, 1999.

[54] J. D. Devine, H. Sigurdsson, A. N. Davis, and S. Self, "Estimates of sulfur and chlorine yield to the atmosphere from volcanic eruptions and potential climatic effects," Journal of Geophysical Research, vol. 89, no. 7, pp. 6309-6325, 1984.

[55] T. M. Gerlach, H. R. Westrich, and R. B. Symonds, "Preeruption vapor in magma of the climatic Mount Pinatubo eruption: source of the giant stratospheric sulfur dioxide cloud," in Fire and Mud: Eruptions and Lahars of Mount Pinatubo, Philippines, C. G. Newhall and R. S. Punongbayan, Eds., pp. 415-433, University of Washington Press, Seattle, Wash, USA, 1996.
[56] P. J. Wallace, "Volcanic $\mathrm{SO}_{2}$ emissions and the abundance and distribution of exsolved gas in magma bodies," Journal of Volcanology and Geothermal Research, vol. 108, no. 1-4, pp. 85106, 2001.

[57] S. Self and A. J. King, "Petrology and sulfur and chlorine emissions of the 1963 eruption of Gunung Agung, Bali, Indonesia," Bulletin of Volcanology, vol. 58, no. 4, pp. 263-285, 1996.

[58] R. J. Andres, W. I. Rose, P. R. Kyle et al., "Excessive sulfur dioxide emissions from Chilean volcanoes," Journal of Volcanology and Geothermal Research, vol. 46, no. 3-4, pp. 323-329, 1991.

[59] H. Shinohara, "Excess degassing from volcanoes and its role on eruptive and intrusive activity," Reviews of Geophysics, vol. 46, no. $4,2008$.

[60] P. J. Wallace and T. M. Gerlach, "Magmatic vapor source for sulfur dioxide released during volcanic eruptions: evidence from Mount Pinatubo," Science, vol. 265, no. 5171, pp. 497-499, 1994.

[61] J. C. M. de Hoog, K. H. Hattori, and R. P. Hoblitt, "Oxidized sulfur-rich mafic magma at Mount Pinatubo, Philippines," Contributions to Mineralogy and Petrology, vol. 146, no. 6, pp. 750-761, 2004.

[62] C. Annen, J. D. Blundy, and R. S. J. Sparks, "The genesis of intermediate and silicic magmas in deep crustal hot zones," Journal of Petrology, vol. 47, no. 3, pp. 505-539, 2006.

[63] M. Edmonds, "New geochemical insights into volcanic degassing," Philosophical Transactions of the Royal Society A, vol. 366, no. 1885, pp. 4559-4579, 2008.

[64] J. Roberge, H. Delgado-Granados, P. J. Wallace, and A. J. Kent, "Pre-eruptive volatile contents of mafic magma at Popocatepetl volcano, Mexico, from olivine-hosted melt inclusions," Eos Transactions AGU 88, Fall meeting supplement, abstract V41D0794, 2007.

[65] G. Hoshyaripour, M. Hort, and B. Langmann, "How does the hot core of a volcanic plume control the sulfur speciation in volcanic emission?" Geochemistry, Geophysics, Geosystems, vol. 13, no. 7, 2012.

[66] L. Caricchi, L. Burlini, P. Ulmer, T. Gerya, M. Vassalli, and P. Papale, "Non-Newtonian rheology of crystal-bearing magmas and implications for magma ascent dynamics," Earth and Planetary Science Letters, vol. 264, no. 3-4, pp. 402-419, 2007.

[67] A. Folch and J. Martí, "Time-dependent chamber and vent conditions during explosive caldera-forming eruptions," Earth and Planetary Science Letters, vol. 280, no. 1-4, pp. 246-253, 2009.

[68] W. I. Rose, "Scavenging of volcanic aerosol by ash: atmospheric and volcanologic implications," Geology, vol. 5, pp. 621-624, 1977.

[69] C. Textor, H.-F. Graf, M. Herzog, and J. M. Oberhuber, "Injection of gases into the stratosphere by explosive volcanic eruptions," Journal of Geophysical Research, vol. 108, no. 19, 2003.

[70] F. Farges, H. Keppler, A. M. Flank, and P. Lagarde, "Sulfur Kedge XANES study of S sorbed onto volcanic ashes," Journal of Physics: Conference Series, vol. 190, no. 1, Article ID 012177, 2009.

[71] B. Langmann, A. Folch, M. Hensch, and V. Matthias, "Volcanic ash over Europe during the eruption of Eyjafjallajökull on Iceland, April-May 2010," Atmospheric Environment, vol. 48, pp. $1-8,2012$.

[72] A. A. Colgate and T. Sigurgeirsson, "Dynamic mixing of water and lava," Nature, vol. 244, no. 5418, pp. 552-555, 1973.

[73] T. M. Wilson, C. Stewart, V. Sword-Daniels et al., "Volcanic ash impacts on critical infrastructure," Physics and Chemistry of the Earth, vol. 45-46, pp. 5-23, 2011. 
[74] P. M. Ayris and P. Delmelle, "The immediate environmental effects of tephra emission," Bulletin of Volcanology, vol. 74, pp. 1905-1936, 2012.

[75] M. R. James, L. Wilson, S. J. Lane et al., "Electrical charging of volcanic plumes," Space Science Reviews, vol. 137, no. 1-4, pp. 399-418, 2008.

[76] S. R. McNutt and E. R. Williams, "Volcanic lightning: global observations and constraints on source mechanisms," Bulletin of Volcanology, vol. 72, no. 10, pp. 1153-1167, 2010.

[77] A. Getahun, M. H. Reed, and R. Symonds, "Mount St. Augustine volcano fumarole wall rock alteration: mineralogy, zoning, composition and numerical models of its formation process," Journal of Volcanology and Geothermal Research, vol. 71, no. 24, pp. 73-107, 1996.

[78] F. Africano and A. Bernard, "Acid alteration in the fumarolic environment of Usu volcano, Hokkaido, Japan," Journal of Volcanology and Geothermal Research, vol. 97, no. 1-4, pp. 475495, 2000.

[79] A. Burgisser and B. Scaillet, "Redox evolution of a degassing magma rising to the surface," Nature, vol. 445, no. 7124, pp. 194197, 2007.

[80] N. Óskarsson, "The interaction between volcanic gases and tephra: fluorine adhering to tephra of the 1970 Hekla eruption," Journal of Volcanology \& Geothermal Research, vol. 8, no. 2-4, pp. 251-266, 1980.

[81] F. H. Verhoff and J. T. Banchero, "Predicting dew points of gases," Chemical Engineering Progress, vol. 78, pp. 71-72, 1974.

[82] E. Bagnato, A. Aiuppa, A. Bertagnini et al., "Scavenging of sulphur, halogens and trace metals by volcanic ash: the 2010 Eyjafjallajökull eruption," Geochimica et Cosmochimica Acta, vol. 103, pp. 138-160, 2013.

[83] J. M. de Moor, T. P. Fischer, D. R. Hilton, E. Hauri, and L. A. Jaffe, "Degassing at Anatahan volcano during the May 2003 eruption: implications from petrology, ash leachates, and $\mathrm{SO}_{2}$ emissions," Journal of Volcanology and Geothermal Research, vol. 146, no. 1-3, pp. 117-138, 2005.

[84] C. S. Witham, C. Oppenheimer, and C. J. Horwell, "Volcanic ash-leachates: a review and recommendations for sampling methods," Journal of Volcanology and Geothermal Research, vol. 141, no. 3-4, pp. 299-326, 2005.

[85] P. Frogner, S. R. Gíslason, and N. Óskarsson, "Fertilizing potential of volcanic ash in ocean surface water," Geology, vol. 29, no. 6, pp. 487-490, 2001.

[86] S. Duggen, N. Olgun, P. Croot et al., "The role of airborne volcanic ash for the surface ocean biogeochemical iron-cycle: a review," Biogeosciences, vol. 7, no. 3, pp. 827-844, 2010.

[87] P. S. Taylor and R. E. Stoiber, "Soluble material on ash from active Central American volcanoes," Geological Society of America Bulletin, vol. 84, pp. 1031-1042, 1973.

[88] D. B. Smith, R. A. Zielinski, W. I. Rose Jr., and B. J. Huebert, "Water-soluble material on aerosols collected within volcanic eruption clouds," Journal of Geophysical Research, vol. 87, no. 7, pp. 4963-4972, 1982.

[89] P. Delmelle, M. Lambert, Y. Dufrêne, P. Gerin, and N. Óskarsson, "Gas/aerosol-ash interaction in volcanic plumes: new insights from surface analyses of fine ash particles," Earth and Planetary Science Letters, vol. 259, no. 1-2, pp. 159-170, 2007.

[90] P. M. Ayris and P. Delmelle, "Volcanic and atmospheric controls on ash iron solubility: a review," Physics and Chemistry of the Earth, vol. 45-46, pp. 103-112, 2012.
[91] J. Fero, S. N. Carey, and J. T. Merrill, "Simulating the dispersal of tephra from the 1991 Pinatubo eruption: implications for the formation of widespread ash layers," Journal of Volcanology and Geothermal Research, vol. 186, no. 1-2, pp. 120-131, 2009.

[92] B. Langmann, K. Zakšek, and M. Hort, "Atmospheric distribution and removal of volcanic ash after the eruption of Kasatochi volcano: a regional model study," Journal of Geophysical Research, vol. 115, no. 2, 2010.

[93] A. Tabazadeh and R. P. Turco, "A model for heterogeneous chemical processes on the surfaces of ice and nitric acid trihydrate particles," Journal of Geophysical Research, vol. 98, no. 7, pp. 12727-12740, 1993.

[94] J. H. Seinfeld and S. N. Pandis, Atmospheric Chemistry and Physics: From Air Pollution to Climate Change, John Wiley \& Sons, New York, NY, USA, 2006.

[95] H. Bingemer, H. Klein, M. Ebert et al., "Atmospheric ice nuclei in the Eyjafjallajökull volcanic ash plume," Atmospheric Chemistry and Physics, vol. 12, pp. 857-867, 2012.

[96] N. Meskhidze, W. L. Chameides, A. Nenes, and G. Chen, "Iron mobilization in mineral dust: can anthropogenic $\mathrm{SO}_{2}$ emissions affect ocean productivity?" Geophysical Research Letters, vol. 30, no. 21, 2003.

[97] F. Solmon, P. Y. Chuang, N. Meskhidze, and Y. Chen, "Acidic processing of mineral dust iron by anthropogenic compounds over the north Pacific Ocean," Journal of Geophysical Research, vol. 114, no. 2, 2009.

[98] N. Meskhidze, W. L. Chameides, and A. Nenes, "Dust and pollution: a recipe for enhanced ocean fertilization?" Journal of Geophysical Research, vol. 110, no. 3, 2005.

[99] A. R. Baker and P. L. Croot, "Atmospheric and marine controls on aerosol iron solubility in seawater," Marine Chemistry, vol. 120, no. 1-4, pp. 4-13, 2010.

[100] Z. Shi, M. D. Krom, T. D. Jickels et al., "Impacts on iron solubility in the mineral dust by processes in the source region and the atmosphere: a review," Aeolian Research, vol. 5, pp. 21-42, 2012.

[101] D. Jeong, K. Kim, and W. Choi, "Accelerated dissolution of iron oxides in ice," Atmospheric Chemistry and Physics, vol. 12, pp. 11125-11133, 2012.

[102] W. I. Rose, G. A. Millard, T. A. Mather et al., "Atmospheric chemistry of a 33-34 hour old volcanic cloud from Hekla volcano (Iceland): insights from direct sampling and the application of chemical box modeling," Journal of Geophysical Research, vol. 111, no. 20, 2006.

[103] T. Deshler, B. J. Johnson, and W. R. Rozier, "Balloonborne measurements of Pinatubo aerosol during 1991 and 1992 at $41^{\circ} \mathrm{N}$ : vertical profiles, size distribution, and volatility," Geophysical Research Letters, vol. 20, no. 14, pp. 1435-1438, 1993.

[104] T. Deshler, D. J. Hofmann, B. J. Johnson, and W. R. Rozier, "Balloonborne measurements of the Pinatubo aerosol size distribution and volatility at Laramie, Wyoming during the summer of 1991," Geophysical Research Letters, vol. 19, no. 2, pp. 199-202, 1992.

[105] P. J. Sheridan, R. C. Schnell, D. J. Hofmann, and T. Deshler, "Electron microscope studies of Mt. Pinatubo aerosol layers over Laramie, Wyoming during summer 1991," Geophysical Research Letters, vol. 19, no. 2, pp. 203-206, 1992.

[106] P. Hamill, E. J. Jensen, P. B. Russell, and J. J. Bauman, “The life cycle of stratospheric aerosol particles," Bulletin of the American Meteorological Society, vol. 78, no. 7, pp. 1395-1410, 1997.

[107] N. A. Fuchs, The Mechanics of Aerosols, Pergamon Press, London, UK, 1964. 
[108] J. T. Kiehl and B. P. Briegleb, "The relative roles of sulfate aerosols and greenhouse gases in climate forcing," Science, vol. 260, no. 5106, pp. 311-314, 1993.

[109] G. K. Yue, L. R. Poole, P.-H. Wang, and E. W. Chiou, "Stratospheric aerosol acidity, density, and refractive index deduced from SAGE II and NMC temperature data," Journal of Geophysical Research, vol. 99, no. 2, pp. 3727-3738, 1994.

[110] P. J. Rasch, S. Tilmes, R. P. Turco et al., "An overview of geoengineering of climate using stratospheric sulphate aerosols," Philosophical Transactions of the Royal Society A, vol. 366, no. 1882, pp. 4007-4037, 2008.

[111] T. -I. Witt, Modelling the atmospheric dispersion and sedimentation of volcanic ash and sulphur of the August 1991 Cerro Hudson eruption [M.S. thesis], Institute of Geophysics, University of Hamburg, Hamburg, Germany, 2013.

[112] A. J. Prata and A. T. Prata, "Eyjafjallajökull volcanic ash concentrations determined using spin enhanced visible and infrared imager measurements," Journal of Geophysical Research, vol. 117, no. 20, 2012.

[113] H. N. Webster, D. J. Thomson, B. T. Johnson et al., "Operational prediction of ash concentrations in the distal volcanic cloud from the 2010 Eyjafjallajökull eruption," Journal of Geophysical Research, vol. 117, no. 2, 2012.

[114] C. E. Junge and J. E. Manson, "Stratospheric aerosol studies," Journal of Geophysical Research, vol. 66, pp. 2163-2182, 1961.

[115] G. S. Kent and M. P. McCormick, "SAGE and SAM II measurements of global stratospheric aerosol optical depth and mass loading," Journal of Geophysical Research, vol. 89, no. 4, pp. 5303-5314, 1984.

[116] U. Jäger, H. Uchino, O. Nagai, T. Fujimoto, T. Freudenthaler, and V. Homburg, "Ground-based remote sensing of the decay of the Pinatubo eruption cloud at three Northern hemisphere sites," Geophysical Research Letters, vol. 22, no. 5, pp. 607-610, 1995.

[117] A. Ansmann, I. Mattis, U. Wandinger, F. Wagner, J. Reichardt, and T. Deshler, "Evolution of the Pinatubo aerosol: raman lidar observations of particle optical depth, effective radius, mass, and surface area over central Europe at $53.4^{\circ} \mathrm{N}$," Journal of the Atmospheric Sciences, vol. 54, no. 22, pp. 2630-2641, 1997.

[118] J. E. Barnes and D. J. Hofmann, "Lidar measurements of stratospheric aerosol over Mauna Loa Observatory," Geophysical Research Letters, vol. 24, no. 15, pp. 1923-1926, 1997.

[119] T. Deshler, J. B. Liley, G. Bodeker, W. A. Matthews, and D. J. Hoffmann, "Stratospheric aerosol following Pinatubo, comparison of the north and south mid latitudes using in situ measurements," Advances in Space Research, vol. 20, pp. 20572061, 1997.

[120] G. J. Symons, The Eruption of Krakatoa, and Subsequent Phenomena, Trübner, London, UK, 1888.

[121] A. Robock and M. Matson, "Circumglobal transport of the El Chichón volcanic dust cloud," Science, vol. 221, no. 4606, pp. 195-197, 1983.

[122] G. J. S. Bluth, S. D. Doiron, S. C. Schnetzler, A. J. Krueger, and L. S. Walter, "Global tracking of the $\mathrm{SO}_{2}$ clouds from the June, 1991 Mount Pinatubo eruptions," Geophysical Research Letters, vol. 19, no. 2, pp. 151-154, 1992.

[123] I. J. Barton, A. J. Prata, I. G. Watterson, and S. A. Young, "Identification of the Mount Hudson volcanic cloud over SE Australia," Geophysical Research Letters, vol. 19, no. 12, pp. 12111214, 1992.

[124] M. R. Schoeberl, S. D. Doiron, L. R. Lait, P. A. Newman, and A. J. Krueger, "A simulation of the Cerro Hudson $\mathrm{SO}_{2}$ cloud,"
Journal of Geophysical Research, vol. 98, no. 2, pp. 2949-2955, 1993.

[125] C. R. Trepte and M. H. Hitchman, "Tropical stratospheric circulation deduced from satellite aerosol data," Nature, vol. 355, no. 6361, pp. 626-628, 1992.

[126] C. R. Trepte, R. E. Veiga, and M. P. McCormick, "The poleward dispersal of Mount Pinatubo volcanic aerosol," Journal of Geophysical Research, vol. 98, pp. 18563-18573, 1993.

[127] J. R. Holton, P. H. Haynes, M. E. McIntyre, A. R. Douglass, R. B. Rood, and L. Pfister, "Stratosphere-troposphere exchange," Reviews of Geophysics, vol. 33, no. 4, pp. 403-439, 1995.

[128] R. Jaenicke, "Über die Dynamik atmosphärischer Aitkenteilchen," Berichte der Bunsengesellschaft für Physikalische Chemie, vol. 82, no. 11, pp. 1198-1202, 1978.

[129] J. P. Pinto, R. P. Turco, and O. B. Toon, "Self-limiting physical and chemical effects in volcanic eruption clouds," Journal of Geophysical Research, vol. 94, no. 8, pp. 11165-11174, 1989.

[130] F. Kasten, "Falling speed of aerosol particles," Journal of Applied Meteorology, vol. 7, pp. 944-947, 1968.

[131] P. Stier, J. Feichter, S. Kinne et al., “The aerosol-climate model ECHAM5-HAM," Atmospheric Chemistry and Physics, vol. 5, no. 4, pp. 1125-1156, 2005.

[132] W. I. Rose and A. J. Durant, "Fate of volcanic ash: aggregation and fallout," Geology, vol. 39, no. 9, pp. 895-896, 2011.

[133] R. J. Brown, C. Bonadonna, and A. J. Durant, "A review of volcanic ash aggregation," Physics and Chemistry of the Earth, vol. 45-46, pp. 65-78, 2012.

[134] A. J. Durant, W. I. Rose, A. M. Sarna-Wojcicki, S. Carey, and A. C. M. Volentik, "Hydrometeor-enhanced tephra sedimentation: constraints from the 18 May 1980 eruption of Mount St. Helens," Journal of Geophysical Research, vol. 114, no. 3, 2009.

[135] C. Bonadonna and A. Foch, "Ash Dispersal Forecast and Civil Aviation Workshop-Consensual Document," 2011, https://vhub.org/resources/503.

[136] A. Folch, "A review of tephra transport and dispersal models: evolution, current status and future perspectives," Journal of Volcanology and Geothermal Research, vol. 235, pp. 96-115, 2012.

[137] C. Gao, A. Robock, and C. Ammann, "Volcanic forcing of climate over the past 1500 years: an improved ice core-based index for climate models," Journal of Geophysical Research, vol. 113 , no. $23,2008$.

[138] T. J. Crowley and M. B. Unterman, "Technical details concerning development of a 1200-yr proxy index for global volcanism," Earth System Science Data, vol. 5, pp. 187-197, 2013.

[139] C. Mass and A. Robock, "The short-term influence of the Mount St. Helens volcanic eruption on surface temperature in the northwest United States," Monthly Weather Review, vol. 110, no. 6, pp. 614-619, 1982.

[140] P. J. Crutzen, "Albedo enhancement by stratospheric sulfur injections: a contribution to resolve a policy dilemma?" Climatic Change, vol. 77, no. 3-4, pp. 211-220, 2006.

[141] C. J. Preston, "Ethics and geoengineering: reviewing the moral issues raised by solar radiation management and carbon dioxide removal," Wiley Interdisciplinary Reviews, vol. 4, no. 1, pp. 23-37, 2013.

[142] S. Twomey, "The influence of pollution on the shortwave albedo of clouds," Journal of Atmospheric Sciences, vol. 34, pp. 1149-1152, 1977.

[143] B. A. Albrecht, "Aerosols, cloud microphysics, and fractional cloudiness," Science, vol. 245, no. 4923, pp. 1227-1230, 1989. 
[144] D. Rosenfeld, U. Lohmann, G. B. Raga et al., "Flood or drought: how do aerosols affect precipitation?" Science, vol. 321, no. 5894, pp. 1309-1313, 2008.

[145] D. Rosenfeld, Y. Rudich, and R. Lahav, "Desert dust suppressing precipitation: a possible desertification feedback loop," Proceedings of the National Academy of Sciences of the United States of America, vol. 98, no. 11, pp. 5975-5980, 2001.

[146] S. Gasso, "Satellite observations of the impact of weak volcanic activity on marine clouds," Journal of Geophysical Research, vol. 113, no. 14, 2008.

[147] F. J. Nober, H.-F. Graf, and D. Rosenfeld, "Sensitivity of the global circulation to the suppression of precipitation by anthropogenic aerosols," Global and Planetary Change, vol. 37, no. 1-2, pp. 57-80, 2003.

[148] H. R. Pruppacher and J. D. Klett, Microphysics of Clouds and Precipitation, Kluwer, Dordrecht, The Netherlands, 2nd edition, 1997.

[149] A. J. Durant, R. A. Shaw, W. I. Rose, Y. Mi, and G. G. J. Ernst, "Ice nucleation and overseeding of ice in volcanic clouds," Journal of Geophysical Research, vol. 113, no. 9, 2008.

[150] P. Seifert, A. Ansmann, S. Groß et al., "Ice formation in ashinfluenced clouds after the eruption of the Eyjafjallajökull volcano in April 2010," Journal of Geophysical Research, vol. 116, no. 18, 2011.

[151] B. D. Santer, M. F. Wehner, T. M. L. Wigley et al., "Contributions of anthropogenic and natural forcing to recent tropopause height changes," Science, vol. 301, no. 5632, pp. 479-483, 2003.

[152] J. A. Church, N. J. White, and J. M. Arblaster, "Significant decadal-scale impact of volcanic eruptions on sea level and ocean heat content," Nature, vol. 438, no. 7064, pp. 74-77, 2005.

[153] K. Trenberth and A. Dai, "Effects of Mount Pinatubo volcanic eruption on the hydrological cycle as an analog of geoengineering," Geophysical Research Letters, vol. 34, no. 15, 2007.

[154] G. Gu, R. F. Adler, G. J. Huffman, and S. Curtis, "Tropical rainfall variability on interannual-to-interdecadal and longer time scales derived from the GPCP monthly product," Journal of Climate, vol. 20, no. 15, pp. 4033-4046, 2007.

[155] G. Stenchikov, T. L. Delworth, V. Ramaswamy, R. J. Stouffer, A. Wittenberg, and F. Zeng, "Volcanic signals in oceans," Journal of Geophysical Research, vol. 114, no. 16, 2009.

[156] L. M. Mercado, N. Bellouin, S. Sitch et al., "Impact of changes in diffuse radiation on the global land carbon sink," Nature, vol. 458, no. 7241, pp. 1014-1017, 2009.

[157] T. L. Frölicher, F. Joos, C. C. Raible, and J. L. Sarmiento, "Atmospheric $\mathrm{CO}_{2}$ response to volcanic eruptions: the role of ENSO, season, and variability," Global Biogeochemical Cycles, vol. 27, pp. 239-251, 2013.

[158] P. W. Boyd and M. J. Ellwood, "The biogeochemical cycle of iron in the ocean," Nature Geoscience, vol. 3, no. 10, pp. 675-682, 2010.

[159] J. H. Martin, "Glacial-interglacial $\mathrm{CO}_{2}$ change: the iron hypothesis," Paleoceanography, vol. 5, no. 1, pp. 1-13, 1990.

[160] M. T. Jones and S. R. Gislason, "Rapid releases of metal salts and nutrients following the deposition of volcanic ash into aqueous environments," Geochimica et Cosmochimica Acta, vol. 72, no. 15, pp. 3661-3680, 2008.

[161] N. M. Mahowald, A. R. Baker, G. Bergametti et al., "Atmospheric global dust cycle and iron inputs to the ocean," Global Biogeochemical Cycles, vol. 19, no. 4, 2005.

[162] D. M. Gaiero, J.-L. Probst, P. J. Depetris, S. M. Bidart, and L. Leleyter, "Iron and other transition metals in Patagonian riverborne and windborne materials: geochemical control and transport to the southern South Atlantic Ocean," Geochimica et Cosmochimica Acta, vol. 67, no. 19, pp. 3603-3623, 2003.

[163] C. D. O’Dowd, M. C. Facchini, F. Cavalli et al., "Biogenically driven organic contribution to marine aerosol," Nature, vol. 431, no. 7009, pp. 676-680, 2004.

[164] P. Liss, A. Chuck, D. Bakker, and S. Turner, "Ocean fertilization with iron: effects on climate and air quality," Tellus, vol. 57, no. 3, pp. 269-271, 2005.

[165] U. Lohmann and J. Feichter, "Global indirect aerosol effects: a review," Atmospheric Chemistry and Physics, vol. 5, no. 3, pp. 715-737, 2005.

[166] R. A. Feely, S. C. Doney, and S. R. Cooley, "Ocean acidification: present conditions and future changes in a high- $\mathrm{CO}_{2}$ world," Oceanography, vol. 22, no. 4, pp. 36-47, 2009.

[167] L. H. Gu, D. D. Baldocchi, S. C. Wofsy et al., "Response of a deciduous forest to the Mount Pinatubo eruption: enhanced photosynthesis," Science, vol. 299, no. 5615, pp. 2035-2038, 2003.

[168] S. M. Cather, N. W. Dunbar, F. W. McDowell, W. C. McIntosh, and P. A. Scholle, "Climate forcing by iron fertilization from repeated ignimbrite eruptions: the icehouse-silicic large igneous province (SLIP) hypothesis," Geosphere, vol. 5, no. 3, pp. 315-324, 2009.

[169] T. P. Parsons and F. A. Whitney, "Did volcanic ash from Kasatochi in 2008 contribute to a phenomenal increase in Fraser River sockeye salmon (Oncorhynchus nerka) in 2010," Fisheries Oceanography, vol. 21, pp. 374-377, 2012.

[170] N. Olgun, S. Duggen, B. Langmann et al., "Geochemical evidence of oceanic iron fertilization by the Kasatochi volcanic eruption in 2008 and the potential impacts on Pacific sockeye salmon," Marine Ecology Progress Series, vol. 488, pp. 81-88, 2013.

[171] S. McKinnell, "Challenges for the Kasatoshi volcano hypothesis as the cause of a large return of sockeye salmon (Oncorhynchus nerka) to the Fraser River in 2010," Fisheries Oceanography, vol. 22, pp. 337-344, 2013.

[172] IPCC (International Panel of Climate Change) fourth assessment report: climate change, 2007.

[173] A. E. Bourassa, D. A. Degenstein, B. J. Elash, and E. J. Llewellyn, "Evolution of the stratospheric aerosol enhancement following the eruptions of Okmok and Kasatochi: Odin-OSIRIS measurements," Journal of Geophysical Research, vol. 115, no. 13, 2010.

[174] K. Yang, X. Liu, P. K. Bhartia et al., "Direct retrieval of sulfur dioxide amount and altitude from spaceborne hyperspectral UV measurements: theory and application," Journal of Geophysical Research, vol. 115, no. 18, 2010.

[175] B. Kravitz, A. Robock, and A. E. Bourassa, "Negligible climatic effects from the 2008 Okmok and Kasatochi volcanic eruptions," Journal of Geophysical Research, vol. 115, no. 2, 2010.

[176] R. A. Scasso, H. Corbella, and P. Tiberi, "Sedimentological analysis of the tephra from the 12-15 August 1991 eruption of Hudson volcano," Bulletin of Volcanology, vol. 56, no. 2, pp. 121132, 1994.

[177] D. J. Kratzmann, S. N. Carey, J. Fero, R. A. Scasso, and J.A. Naranjo, "Simulations of tephra dispersal from the 1991 explosive eruptions of Hudson volcano, Chile," Journal of Volcanology and Geothermal Research, vol. 190, no. 3-4, pp. 337352, 2010.

[178] J. L. Smellie, “The upper Cenozoic tephra record in the south polar region: a review," Global and Planetary Change, vol. 21, no. 1-3, pp. 51-70, 1999. 
[179] C. Rödenbeck, S. Houweling, M. Gloor, and M. Heimann, " $\mathrm{CO}_{2}$ flux history 1982-2001 inferred from atmospheric data using a global inversion of atmospheric transport," Atmospheric Chemistry and Physics, vol. 3, no. 6, pp. 1919-1964, 2003.

[180] J. Holmes, V. Hall, and P. Wilson, "Volcanoes and peat bogs," Geology Today, vol. 15, no. 2, pp. 60-63, 1999.

[181] G. T. Swindles, F. de Vleeschouwer, and G. Pliunkett, "Dating peat profiles using tephra: stratigraphy, geochemistry and chronology," Mires and Peat, vol. 7, article 5, pp. 1-9, 2010.

[182] T. Deshler, A. Adriani, G. P. Gobbi, and D. J. Hofmann, "Volcanic aerosol and ozone depletion within the Antarctic polar vortex during the Austral spring of 1991," Geophysical Research Letters, vol. 19, no. 18, pp. 1819-1822, 1992.

[183] M. C. Pitts and L. W. Thomason, "The impact of the eruptions of Mount Pinatubo and Cerro Hudson on Antarctic aerosol levels during the 1991 Austral spring," Geophysical Research Letters, vol. 20, no. 22, pp. 2451-2454, 1993.

[184] E. G. Dutton and J. R. Christy, "Solar radiative forcing at selected locations and evidence for global lower tropospheric cooling following the eruptions of El Chichón and Pinatubo," Geophysical Research Letters, vol. 19, no. 23, pp. 2313-2316, 1992.

[185] D. W. J. Thompson, J. M. Wallace, P. D. Jones, and J. J. Kennedy, "Identifying signatures of natural climate variability in time series of global-mean surface temperature: methodology and insights," Journal of Climate, vol. 22, no. 22, pp. 6120-6141, 2009.

[186] K. Labitzke and M. P. McCormick, "Stratospheric temperature increases due to Pinatubo aerosols," Geophysical Research Letters, vol. 19, no. 2, pp. 207-210, 1992.

[187] M. G. Wiesner, A. Wetzel, S. G. Catane, E. L. Listanco, and H. T. Mirabueno, "Grain size, areal thickness distribution and controls on sedimentation of the 1991 Mount Pinatubo tephra layer in the South China Sea," Bulletin of Volcanology, vol. 66, no. 3, pp. 226-242, 2004.

[188] S. Driscoll, A. Bozzo, L. J. Gray, A. Robock, and G. Stenchikov, "Coupled Model Intercomparison Project 5 (CMIP5) simulations of climate following volcanic eruptions," Journal of Geophysical Research, vol. 117, no. 17, 2012.

[189] J. Fierstein and W. Hildreth, "The plinian eruptions of 1912 at Novarupta, Katmai National Park, Alaska," Bulletin of Volcanology, vol. 54, no. 8, pp. 646-684, 1992.

[190] L. Oman, A. Robock, G. Stenchikov, G. A. Schmidt, and R. Ruedy, "Climatic response to high-latitude volcanic eruptions," Journal of Geophysical Research, vol. 110, no. 13, 2005.

[191] J. Fierstein and W. Hildreth, "Preliminary volcano-hazard assessment for the Katmai volcanic cluster, Alaska," OpenFile Report 00-489, U.S. Geological Survey, Anchorage, Alaska, USA, 2001.

[192] V. M. Mantas, A. J. S. C. Pereira, and P. V. Morais, "Plumes of discolored water of volcanic origin and possible implications for algal communities. The case of the Home Reef eruption of 2006 (Tonga, Southwest Pacific Ocean)," Remote Sensing of Environment, vol. 115, no. 6, pp. 1341-1352, 2011.

[193] S. L. de Silva and G. A. Zielinski, "Global influence of the AD 1600 eruption of Huaynaputina, Peru," Nature, vol. 393, no. 6684, pp. 455-458, 1998.

[194] J. M. Palais, S. Kirchner, and R. J. Delmas, "Identification of some global volcanic horizons by major element analysis of fine ash in Antarctic ice," Annals of Glaciology, vol. 14, pp. 216-220, 1990.

[195] C. M. Meure, D. Etheridge, C. Trudinger et al., "Law Dome $\mathrm{CO}_{2}, \mathrm{CH}_{4}$ and $\mathrm{N}_{2} \mathrm{O}$ ice core records extended to 2000 years BP," Geophysical Research Letters, vol. 33, no. 14, 2006.
[196] K. B. Briffa, P. D. Jones, F. H. Schweingruber, and T. J. Osborn, "Influence of volcanic eruptions on Northern Hemisphere summer temperature over the past 600 years," Nature, vol. 393, no. 6684 , pp. 450-455, 1998.

[197] F. Costa, B. Scaillet, and A. Gourgaud, "Massive atmospheric sulfur loading of the AD 1600 Huaynaputina eruption and implications for petrologic sulfur estimates," Geophysical Research Letters, vol. 30, no. 2, 2003.

[198] L. M. Prueher and D. K. Rea, "Rapid onset of glacial conditions in the subarctic North Pacific region at $2.67 \mathrm{Ma}$ : clues to causality," Geology, vol. 26, no. 11, pp. 1027-1030, 1998.

[199] L. M. Prueher and D. K. Rea, "Volcanic triggering of late Pliocene glaciation: evidence from the flux of volcanic glass and ice-rafted debris to the North Pacific Ocean," Palaeogeography, Palaeoclimatology, Palaeoecology, vol. 173, no. 3-4, pp. 215-230, 2001.

[200] G. A. Zielinski, P. A. Mayewski, L. D. Meeker, S. Whitlow, and M. S. Twickler, "Potential atmospheric impact of the Toba mega-eruption $\sim 71,000$ years ago," Geophysical Research Letters, vol. 23, no. 8, pp. 837-840, 1996.

[201] M. D. Petraglia, R. Korisettar, and J. N. Pal, "The Toba volcanic super-eruption of 74,000 years ago: climate change, environments, and evolving humans," Quaternary International, vol. 258, pp. 1-4, 2012.

[202] M. R. Rampino and S. Self, "Climate-volcanism feedback and the Toba eruption of $\sim 74,000$ years ago," Quaternary Research, vol. 40, no. 3, pp. 269-280, 1993.

[203] R. C. Bay, N. E. Bramall, and P. B. Price, "Bipolar correlation of volcanism with millennial climate change," Proceedings of the National Academy of Sciences of the United States of America, vol. 101, no. 17, pp. 6341-6345, 2004.

[204] B. R. Jicha, D. W. Scholl, and D. K. Rea, "Circum-Pacific arc flare-ups and global cooling near the Eocene-Oligocene boundary," Geology, vol. 37, no. 4, pp. 303-306, 2009.

[205] J. C. Zachos, T. M. Quinn, and K. A. Salamy, "High-resolution (104 years) deep-sea foraminiferal stable isotope records of the Eocene-Oligocene climate transition," Paleoceanography, vol. 11, no. 3, pp. 251-266, 1996.

[206] K. A. Salamy and J. C. Zachos, "Latest Eocene-Early Oligocene climate change and Southern Ocean fertility: inferences from sediment accumulation and stable isotope data," Palaeogeography, Palaeoclimatology, Palaeoecology, vol. 145, no. 1-3, pp. 61-77, 1999.

[207] S. Bains, R. D. Norris, R. M. Corfield, and K. L. Faul, “Termination of global warmth at the Palaeocene/Eocene boundary through productivity feedback," Nature, vol. 407, no. 6801, pp. 171-174, 2000.

[208] R. S. Barclay, J. C. McElwain, and B. B. Sageman, "Carbon sequestration activated by a volcanic $\mathrm{CO}_{2}$ pulse during Ocean Anoxic Event 2," Nature Geoscience, vol. 3, pp. 205-208, 2010.

[209] I. Bailey, Q. Liu, G. E. A. Swann et al., "Iron fertilisation and biogeochemical cycles in the sub-Arctic northwest Pacific during the late Pliocene intensification of northern hemisphere glaciation," Earth and Planetary Science Letters, vol. 307, no. 3-4, pp. 253-265, 2011.

[210] A. Martínez-Garcia, A. Rosell-Melé, W. Geibert et al., "Links between iron supply, marine productivity, sea surface temperature, and $\mathrm{CO}_{2}$ over the last 1.1 Ma," Paleoceanography, vol. 24, no. 1, 2009. 

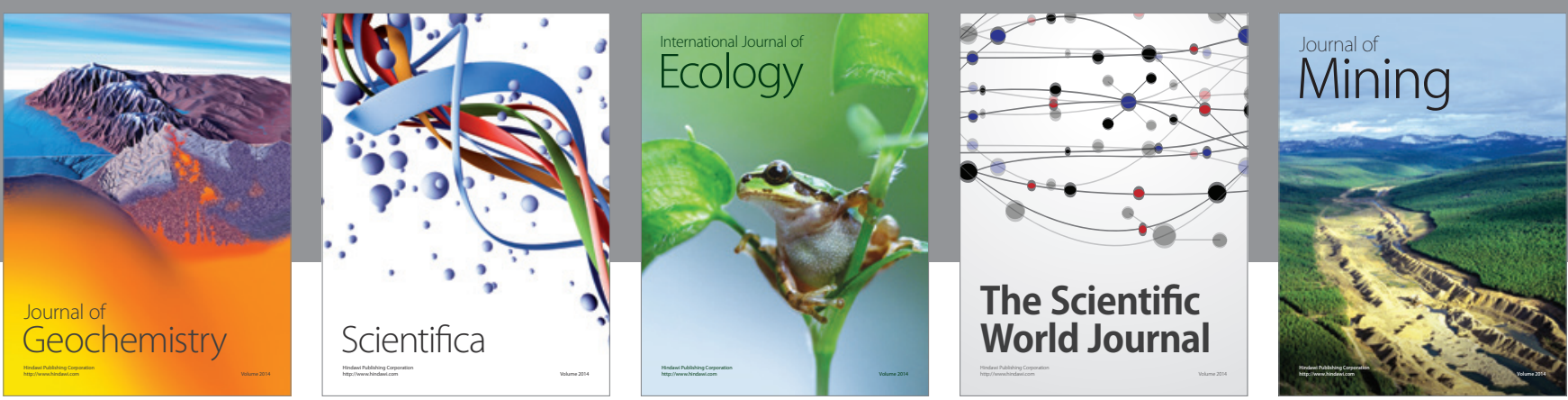

The Scientific World Journal
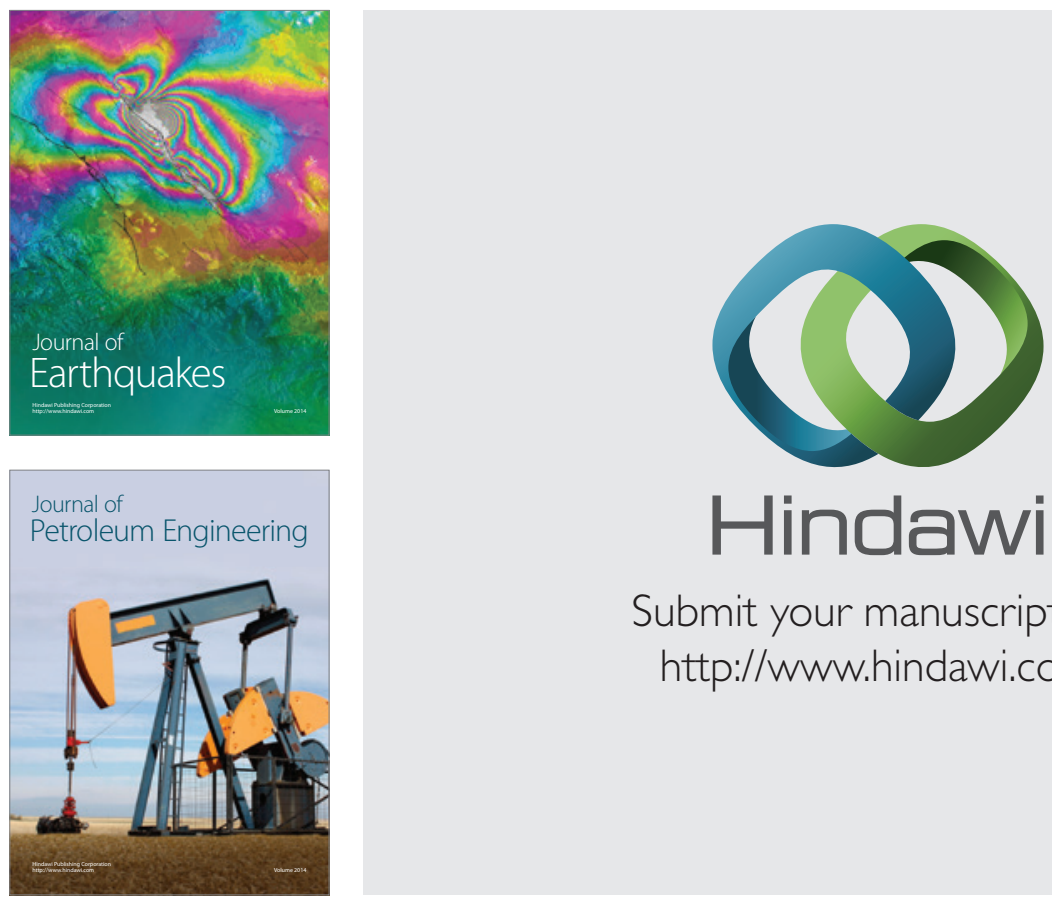

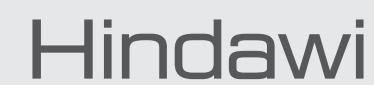

Submit your manuscripts at

http://www.hindawi.com
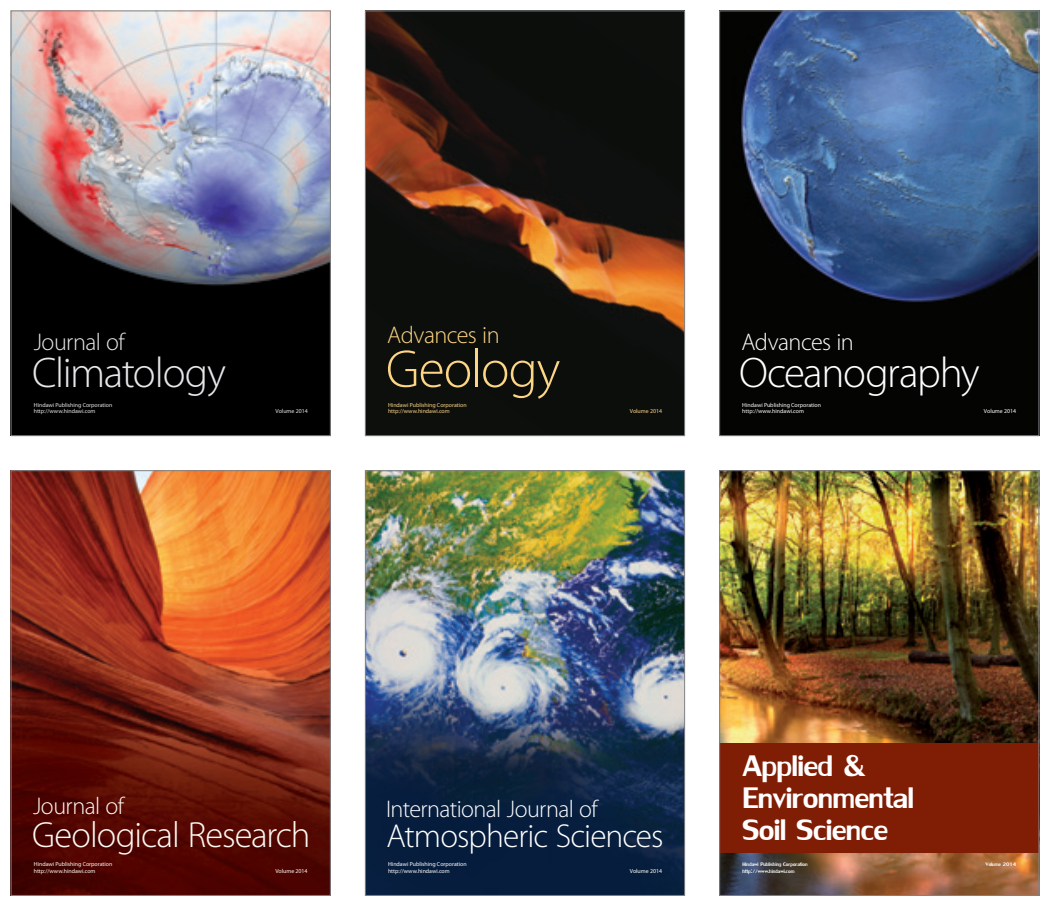
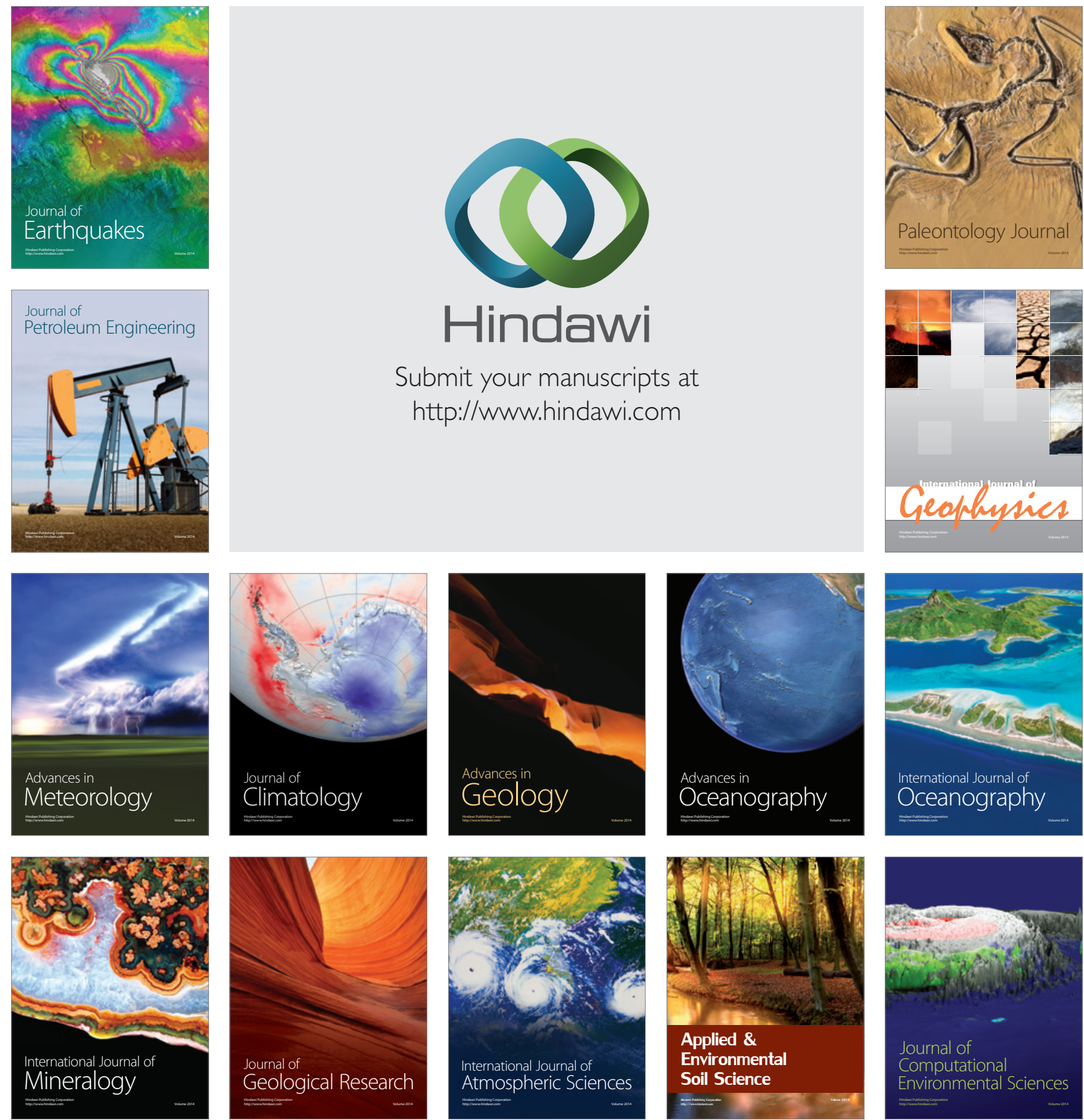